\title{
BIAS IN THE LEGAL PROFESSION: PERCEPTIONS AND EXPERIENCES'
}

\author{
JOAN BROCKMAN"
}

Brockman presents the results of a survey conducted in 1991 for the Law Socicty of Alberta that was designed to determine to what extem gender discrimination actually exists within the legal profession in Alberta. It is one of many sumeys that have been conducted since the 1970s. The survey nas extensive: it asked general questions on bias and discrimination, and it considered how problems have developed and how they have be'n percerived. The results show' as Brockman explains, that there is definitely a problem with gender discrimination within the legal profession which is complicated. for both men and nomen. by marital and family commitments.
Brockman présente les résulhats d'une entuête exhanstive effecmée en 1991 par la Law Society of Alberta "t visant à déterminer l'ampleur de la discrimination fondée sur le sere qui existe parmi les professions die droit en Alheria. Il $s^{\circ}$ agit d'un des nombientex sondages qui ont éte faits depuis les ammées 1970. Tous les membre's de la Law Society

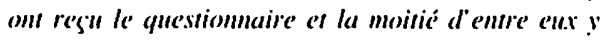
ont répondu. L'enquêté soulèvait des questions générales sur les préjugés et la discrimination.. examinait comment les problemes avaient progressé 't comment ils étaien pergus. Selon Brockman. les résultats montrent qu' il existe un problème víritable de discrimination an sein de la profession. lequel so complique concore - tamt pour les hommes que pour les femmes - par des engagements conjuganter et familianx.

\section{TABLE OF CONTENTS}

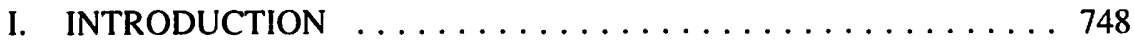

II. A SURVEY OF ACTIVE MEMBERS OF THE

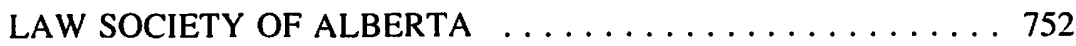

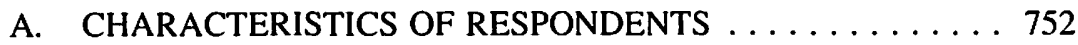

B. PERCEPTION OF GENDER BIAS OR

DISCRIMINATION IN THE LEGAL PROFESSION $\ldots \ldots 755$

C. THE NATURE OF BIAS OR

DISCRIMINATION AGAINST WOMEN $\ldots \ldots \ldots \ldots \ldots 755$

D. THE NATURE OF BIAS OR

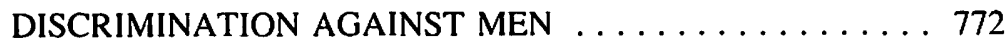

E. DENIAL OF OPPORTUNITIES

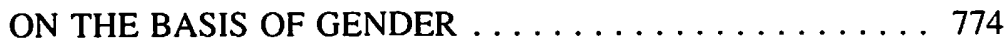

F. PERSONAL EXPERIENCE WITH

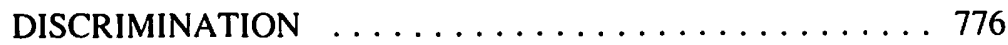

III. CONCLUDING COMMENTS $\ldots \ldots \ldots \ldots \ldots \ldots \ldots \ldots \ldots 782$

Joan Brockman teaches at the school of Criminology, Simon Fraser University. She is also a member of the Law Societies of British Columbia and Alberta (inactive).

1. This paper is based on a survey of active members of the Law Society of Alberta which was conducted for the Joint Committee on Women and the Legal Profession. The views expressed in this paper are those of the author and do not necessarily reflect the views of the Law Society or the Joint Committee on Women in the Legal Profession. I would like to thank members of the Committee for their contributions to drafting the questionnaire. I also thank Bill Glackman for statistical and technical support and Shelly Devon for her editorial comments: the financial support of the Law Foundation of Alberta is gratefully acknowledged. 
A. THE GLASS CEILING AND

THE GLASS BOX ..................... 783

B. LACK OF ACCOMMODATION FOR

FAMILY COMMITMENTS . . . . . . . . . . . . . . 784

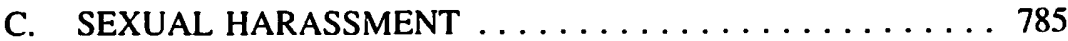

D. OTHER FORMS OF DISCRIMINATION $\ldots \ldots \ldots \ldots \ldots 786$

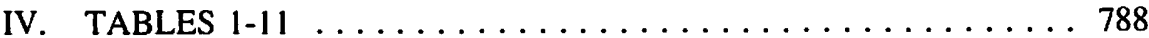

V. Appendix A ....................... 803

\section{INTRODUCTION}

In April of 1990, the Benchers of the Law Society of Alberta established a Committee on Women and the Legal Profession to research and review the issues concerning women in the profession. ${ }^{2}$ This initiative is part of a pattern of studies launched by law societies across Canada. In 1989, the Law Society of Upper Canada's Women in the Legal Profession Committee received a comprehensive report on Women in the Legal Profession in Ontario. ${ }^{3}$ Two years later another report, Transitions in the Ontario Legal Profession, described the results of a survey of Ontario lawyers called to the Bar between 1975 and $1990 .^{+}$

In January of 1992, the Law Society of British Columbia circulated Women in the Legal Profession: A Report of the Women in the Legal Profession Subcommittee to all members of the Society. The Subcommittee, established in January of 1989, had received two reports on the results of surveys of former and current members of the Law Society. ' In June of 1990, the Law Society of British Columbia passed a resolution to create another committee on gender bias. This second Committee's mandate was to inquire into "the existence of gender bias in substantive and procedural law, ...interaction in the courtroom, in legal organizations, the law schools, and in the profession in general." ${ }^{17}$

The Law Society of Saskatchewan, the Canadian Bar Association (Saskatchewan Branch), and the College of Law (University of Saskatchewan) established a Committee

2. Alberta Law Society. Benchers’ Advisory (1990. June) 5-6.

3. F. Kay, Women in the Legal Profession (A Report Submitted to the Law Society of Upper Canada: June, 1989).

4. F. Kay, Transirions in the Omario Legal Profession: A Survey of Lawyers Called to the Bar Between 1975 and 1990 (A Report of the Law Society of Upper Canada: May, 1991).

5. K.P. Young (Chair). Dean L. Smith, F. Watters, K. Nordlinger, Q.C., and W. Wilson, with M. O'Brien (Subcommittee staff), Women in the Legal Profession: A Report of the Women in the Legal Profession Subcommittee (September, 1991).

6. J. Brockman, Encoumering Barriers andlor Moving On: A Survey of Former Members of the Law Society of British Columbia (A Report Prepared for the Law Society of British Columbia's Subcommittec on Women in the Legal Profession. August, 1990) and J. Brockman. Identifying the Barriers: A Survey of Members of the Law Society of British Columbia (A Report Prepared for the Law Society of British Columbia's Subcommittee on Women in the Legal Profession, April, 1991). The reports are Appendices 1 and 2 to the Subcommittee's Report.

7. Benchers' Bulletin (Law Society of British Columbia: February-March, 1991) at 5. The Committce has been holding hearings around British Columbia and is expected to report in June of 1992. 
on Gender Discrimination which surveyed the legal profession, law faculty members, the judiciary, and law students in 1991. The logistics of conducting similar studies are being discussed in Manitoba and Nova Scotia.

A number of activities have also been initiated from outside the law societics. In the summer of 1990, a committee of "senior officials" from the federal, provincial and territorial governments was set up to study the issue of gender equality in the justice system. ${ }^{8}$ In June of 1991, a National Symposium on Women, Law and the Administration of Justice was held in Vancouver. One of the discussion papers addressed the issue of "Sexism and the Legal Profession." In May of 1991, the Canadian Bar Association set up a Task Force on Gender Equality, headed by former Supreme Court of Canada Justice Bertha Wilson, to inquire into the status of women in the legal profession and gender bias in the Canadian Bar Association." In November, 1991, the Vancouver Association of Women and the Law and the Feminist Institute for Studies on Law and Society at Simon Fraser University held a two day Research Consultation on How to Study Gender Bias in the Law, the Courts and the Legal Profession. The Research Consultation brought legal academics and social scientists together with lawyers, judges and members of other organizations concerned with the issues of gender bias, in order to discuss methods and methodological issues associated with the study of gender bias. Professor Mary Jane Mossman wrote a paper for the session on the legal profession." In addition, judicial education programmes on gender issues in the courts have been conducted across Canada. ${ }^{12}$

These recent works were not, however, the first to address issues which women face in the legal profession. A number of studies in the early 1970s identified the difficulties women encountered in the legal profession. In 1970, Cameron Harvey published the

x. "Federal-provincial study focuses on gender bias" Canadian Bar Association National (September. 1990) 7.

4. M.S. Borenstein, "Sexism and the Legal Profession" A Discussion Paper prepared for the National Symposium on Women. Law and the Administration of Justice, Vancouver, British Columbia, June 10-12, 1991.

10. R. Dufton, "CBA Task Force to Study Gender Bias" Canadian Bar Association National (May. 1991) 15. See also: The Canadian Bar Association Task Force on Gender Equality. Terms of Reference (May. 1991).

11. M.J. Mossman. "Gender Bias and the Legal Profession: Challenges and Choices" in J. Brockman and D.E. Chunn, eds., Investigating Gender Bias in Law: Socio-Legal Perspectives (Toronto: Thompson Educational Publishing, Inc., forthcoming).

12. See for example. D. Hackett, Gender Equality (Ottawa: Canadian Judicial Centre for the Education Committee of the Canadian Judicial Council, May, 1990) and Judicial Education Program on Gender Equality (Vancouver: Western Judicial Education Centre. June, 1991). Both programs include material and videos on gender issues in the courts. Judicial neutrality was the subject of a conference held in Banfr in 1986. See S.L. Martin and K.E. Mahoney. eds.. Equality and Judicial Neutrality (Toronto: Carswell, 1987). The Commonwealth of Learning has recently collected information from the National Judicial Institute (formerly the Canadian Judicial Centre), the Western Judicial Education Centre, and other judicial education programmes around the world with a view to evaluating programmes for Distance Education initiatives. See The Commonwealth of Learning. Background Document for the Meeting on Commomwealth Cooperation in Continuing Judicial Education, March 11-13, 1992 Vancouver, British Columbia. 
results of a Canada wide survey of women in the legal profession. The six most common complaints by women were:

that it is much more difficult for women lawyers as opposed to men to obtain a first job or position of employment, that women have to prove themselves (presumably to a greater extent than their male contemporaries), that women receive unequal remuneration and experience unequal advancement in comparison with their male contemporaries unless they are more than obviously deserving. that women are not taken seriously, and that it is common to attempt to "pigeonhole" women into certain routine areas of work. ${ }^{13}$

In 1972, Linda Silver Dranoff published the results of a survey of women lawyers in Toronto and concluded that "traditional excuses for differentiating between female and male lawyers [were] not valid." ${ }^{14}$ In the same year, Lynn Smith, Marylee Stephenson and Gina Quijano undertook a detailed survey and analysis of the experiences of law students and graduates from the University of British Columbia in obtaining articles. They concluded that more men had more choices than the women and that men were more likely to obtain their first choice in articling positions. ${ }^{15}$

A number of studies were also conducted in the $1980 \mathrm{~s} .{ }^{16}$ Of particular interest to Alberta is the study by Delee Fromm and Marjorie Webb which described the work experiences of women and men who had graduated from the University of Alberta between 1975 and $1980 .^{17}$ More recently, Jean E. Wallace reported on a survey of Calgary lawyers which focused on why lawyers quit their jobs. ${ }^{18}$

C. Harvey, "Women in Law in Canada" (1970) 4 Man. L.J. 9 at 11.

L.S. Dranoff. "Women as Lawyers in Toronto" (1972) 10 Osgoode Hall L.J. 177 al 190.

L. Smith. M. Stephenson and G. Quijano. "The Legal Profession and Women: Finding Articles in British Columbia" (1973) 8 U.B.C. L. Rev. 137 at 162. See also J.K. Bankier. "Women in the Law School: Problems and Potential" (1974) 22 Chitty's L.J. 171.

th. See for example, B.D. Adam and D.E. Baer, "The Social Mobility of Women and Men in the Ontario Legal Profession" (1984) 21 Canadian Review of Sociology and Anthropology 21; B.D. Adam \& K.A. Lahey, "Professional Opportunities: A Survey of the Ontario Legal Profession" (1981) 59 Can. Bar Rev. 674: G. Stanley. Progress and Procrastination: Maternity Benefits For Lawyers in Vanconver, ed. by F.R. Watters. (Vancouver: Vancouver Association of Women and the Law, October, 1987); J. Savarese, M. Keet and K. Sutherland, Survey of Women Graduates from the College of Lan' (University of Saskatchewan: Woman and the Law, 1988); M. Brown and H. Penner. Gender Equality in the Courts: A Study for the Manitoba Association of Women and the Lan' (Ottawa: National Association of Women and the Law, 1988), at 30-33; J. Hagan. M. Huxter and P. Parker. "Class Structure and Legal Practice: Inequality and Mobility Among Toronto Lawyers" (1988) 22 Law and Society Review 9; J. Hagan. "The Gender Stratification of Income Inequality Among Lawyers" (1990) 68 Social Forces 835.

D. Fromm and M. Webb. "The Work Experience of University of Alberta Law Graduates" (1985) 23 Alta L. Rev. 366: a paper which is based on their report: D. Fromm \& M. Webb. A Question of Equality: A Comparative Study of the 1975 to 1980 Lan Graduates from the University of Alberta (September, 1984).

J.E. Wallace. Why Lawyers Decide to Quit Their Jobs: A Study of Job Satisfaction and Organizational Commimemt Among Calgary Lawyers (October, 1991). 
Between 1987-1991, women represented $45 \%$ of students admitted to the two law schools in Alberta, $43 \%$ of the graduates, ${ }^{19}$ and $36 \%$ of lawyers called to the Bar in Alberta. $^{20}$ In 1991, women represented $20 \%$ of the active members of the Law Society of Alberta. ${ }^{21}$ With the increasing number of women in the legal profession and the disproportionate numbers leaving the profession,"2 law societies across Canada have decided to address some of the issues which both women and men are encountering in what is still a male dominated profession.

Concern with the plight of women in male-dominated occupations is not limited to the legal profession. ${ }^{23}$ More recently the study of bias in the legal profession and the judicial system has been expanded to include discrimination against racial minorities, the disabled, lesbians and gay men. ${ }^{24}$

This paper describes the results of a survey of active members of the Law Society of Alberta which was conducted for the Joint Committee on Women and the Legal Profession and adds some comparative data from a survey of members of the Law Society of British Columbia. ${ }^{25}$ The purpose of both surveys was to develop a largely descriptive profile of active members of the law societies and their perceptions regarding a number of issues: Are women encountering barriers in the legal profession which are different from those encountered by men? Do members think that there is bias or discrimination in the legal profession, and if so, how is it manifested? How do active members of the Law Society combine marriage and children with the practice of law?

These figures were compiled by the Office of the Registrar, University of Alberta and the Faculty of Law, University of Calgary.

20. Numbers from the Law Society of Alberta.

21. In comparison, women made up 22\% of the legal profession in British Columbia in 1991. See J. Brockman. "'Resistance by the Club" to the Feminization of the Legal Profession" (1992) 7 Canadian Journal of Law and Sociely (forthcoming).

22. A study of former members of the Law Society of British Columbia showed that $22 \%$ of the women, but only $13 \%$ of the men, who were called to the Bar between 1974 and 1988 were no longer members in 1990. Despite the higher attrition rates for women, men represented $62 \%$ of those who had not renewed their memberships, ibid. See also Kay, supra. note 4 at 98 . where it is reported that while women represented 30\% of those called to the Bar in Ontario between 1975 and 1990. they represented 37\% of those who were no longer practising law.

23. See for example. The Report of the Task Force on Barricrs to Women in the Public Service. Beneath the Veneer (Ottawa: Canadian Government Publishing Centre, 1990); C. Maille, Primed For Power: Women in Canalian Politics (Ottawa: Canadian Advisory Council on the Status of Women. 1990): and M. Belcourt, R.J. Burke. \& H. Lee-Gosselin, The Glass Bor: Women Business Owners in Canada (Ottawa: Canadian Advisory Council on the Status of Women, 1991).

The Law Society of British Columbia's Committee on Gender Bias has heard from other disadvantaged groups even though its focus was women. The Western Judicial Education Centre is presently preparing a programme on Race and Ethnic Relations for Junc. 1992. Also see S. Razack, "Exploring the omissions and silences in law around race" in J. Brockman \& D.E. Chunn. eds.. Investigating Gender Bias in Lan: Socio-Legal Perspectives (Toronto: Thompson Educational Publishing Inc.. forthcoming).

2s. See J. Brockman. "Gender Bias in the Legal Profession: A Survey of Members of the Law Society of British Columbia" (1992) 17 Queen's L. 3. 91. which presents some of the findings from Brockman, Identifying the Barriers, sapra, note 6. 


\section{A SURVEY OF ACTIVE MEMBERS OF THE LAW SOCIETY OF ALBERTA}

A six page questionnaire ${ }^{26}$ was sent to all lawyers ( 972 women and 3817 men) who were active members of the Law Society of Alberta as of April 23, 1991 and who resided in the province. The questionnaire (see Appendix A) was introduced by a covering letter from Peter Freeman, Q.C., the Secretary of the Law Society. Questionnaires were mailed out on April 23, 1991, and reminder letters were sent out on May 23, 1991 and June 17, 1991. The last questionnaire used in this paper was received back on September 12, $1991 . .^{27}$

\section{A. CHARACTERISTICS OF RESPONDENTS}

Questionnaires were returned by 600 women and 1798 men, for an overall response rate of $50 \%$. The response rate was higher for women $(62 \%)$ than for men $(47 \%),{ }^{28}$ and it was higher for both younger women and men.

The median"9 year of call for the women respondents was 1985 and for the men, $1980 ;{ }^{30} 42.9 \%$ of the women, as compared to $22.2 \%$ of the men, were called after 1985 ; $77.1 \%$ of the women, as compared to $47.8 \%$ of the men, were called after 1980 . This reflects, in part, the fact that women have only recently been admitted to the bar in any significant number. The earliest year of call in Alberta was 1952 for women respondents and 1945 for men. The mean age (arithmetic average) of the women was 35.3, as compared to 39.5 for the men.

Seventy-five percent of the women, as compared to $83.8 \%$ of the men, were living in a married or equivalent relationship. A zero order gamma ${ }^{31}$ of .27 shows a fairly strong

20. Members of Alberta's Joint Committee on Women and the Legal Profession reviewed a questionnaire which was developed by the author in collaboration with members of the Law Society of British Columbia's Subcommittee on Women in the Legal Profession. Many of the questions for this survey are the same as those used in British Columbia; however, some have been changed, and others have been added or deleted in order to make the questions relevant to the legal profession in Alberta and to the interests of the members on the Alberta Committee.

27. Questionnaires were mailed out in January of 1990 in British Columbia and the last questionnaire used was received back in September, 1990.

2x. This is considered a good response rate by conventional research standards. The overall response rate for members of the Law Society of British Columbia was $29 \%$. It was higher for women (53\%) than for men (23\%). Supra, note 25.

2. The median is the point which divides the number of respondents into two halves, with one-half of the respondents above the median and one-half below it.

30. The median year of call in the British Columbia survey was 1985 for the women, and 1981 for the men. Supra, note 25.

31. Gamma is a measure of association between two ordinal variables which indicates the degree to which one variable can be predicted with knowledge of the other. A gamma value can range from 1.0 (a perfect negative relationship between two variables) to +1.0 (a perfect positive relationship between two variables). A value of +1.0 or -1.0 would allow for $100 \%$ predictability of, for example, marital status, given the sex of the respondent. A 0.0 value indicates that there is no predictive value between the two variables. A zero order gamma measures the relationship between two variables without controlling for other variables. A partial gamma shows the relationship 
relationship between gender and "marital status." Table $1^{32}$ shows that there was little difference between the women and men who were under 35 years of age, except that the women under 30 were more likely to be living in a married or equivalent relationship than the men who were under $30 .{ }^{33}$

There was a difference in the 35 plus age group which increased with the age of the respondents. Only $65 \%$ of women in the $45+$ age group were living in a married or equivalent relationship, as compared to $88 \%$ of the men. The conditional gamma of .61 establishes a strong relationship between gender and marital status for this age group. The

between two variables (e.g. gender and marital status in Table I) while controlling for a third variable (age). A conditional gamma is a measure of association between two variables (e.g. gender and marital status) within a category of a third variable (e.g. age 40-44). When comparing differences between women and men by the use of this measure of association, the following descriptive words are used to describe the strength of the relationships:

$\begin{array}{ll}\text { Gamma } & \text { Descriptive Words } \\ .50 \text { or }> & \text { "strong relationship" } \\ .25-.49 & \text { "fairly strong relationship" } \\ .20-.24 & \text { "some relationship" } \\ .15-.19 & \text { "weak relationship" } \\ <.15 & \text { "no relationship" }\end{array}$

For a discussion of the interpretation and limitations of measures of association, sec, for example, J.H. Mueller, K.F. Schuessler \& H.L. Costner, Statistical Reasoning in Sociology (Boston: Houghton Mifflin, 1977).

Tests of significance are also given for these tables but have to be interpreted with caution because of the possibility that the assumptions which have to be made when using them may not have been met. The following symbols have been used to describe the probability (measured by Chi-Square) that the results in the tables could be explained by chance:

$\begin{array}{ll}\text { Symbol } & \text { Chi-Square } \\ * * & <.05 \\ * * * & <.01 \\ & <.001\end{array}$

For example, * indicates that the result is statistically significant at the $5 \%$ level or $\mathrm{p}<.05$, maning that such a result would occur by chance in a sample less than 5 times out of 100 . For further information on the use of tests of significance see for cxample. R.F. Winch and D.T. Campbell, "Proof? No. Evidence? Yes. The Significance of Tests of Significance" (1969) 4 American Sociologist 140; and Blalock, Social Statistics (New York: McGraw-Hill, 1979).

It should also be remembered that tests of significance do not say anything about the substantive importance of findings but, rather. are limited to saying something about the probability that the findings in a random sample can be explained by chance.

Table 1 is a three-variable cross-tabulation. It shows the relationship between two variables (gender and marital status) within categories of a third variable (age). Such tables can assist in illustrating that a relationship between two variables is spurious (the function of a third variable) or that additional variables are intervening in the relationship. If there are additional variables influencing a statistical relationship, the decision as to whether the first correlation is spurious or whether there are intervening variables is not determined statistically, but rather theoretically. For further information on these and other possible effects of additional variables in elaboration analysis, see $M$. Rosenberg. The Logic of Survey Analysis (New York: Basic Books. Inc., 1968); or T. Hirschi \& H.C. Selvin. Principles of Survey Analysis (New York: The Free Press. 1973).

The relationship was not statistically significant at $\mathrm{p}<.05$. There was little difference in marital status among the respondents who were under $\mathbf{3 0}$ years of age in the British Columbia survey. 59\% of the women and $61 \%$ of the men were living in a married or equivalent relationship. See Brockman, Identifying the Barriers, supra note 6 at 15. 
difference drops somewhat for the $40-44$ age group; only $78 \%$ of these women as compared to $89 \%$ of the men were living in a married or equivalent relationship. The conditional gamma (.40) shows a strong relationship between gender and marital status for the $40-44$ age group. ${ }^{3.4}$

Only $52.7 \%$ of the women in this survey, as compared to $70.8 \%$ of the men, had children. ${ }^{35}$ The zero order gamma for this relationship, .39 , indicates a fairly strong relationship between gender and number of children. Of those respondents who had children, the women had an average of 2.0 children and the men had an average of 2.5 children.

Table 2 shows that parenthood for the women and men in this survey varied with age. In all age categories, the men were more likely than the women to have children, and to have two or more children. The difference between the women and the men increases with the age of the respondents. ${ }^{36}$ Only $66 \%$ of the women in the 40 and older age group had children, as compared to $84 \%$ of the men. The conditional gamma (.43) for this relationship is fairly strong. A further analysis shows that $10 \%$ of the women who had children were not living in a married or equivalent relationship, as compared to $4 \%$ of the men. ${ }^{37}$ The gamma for this relationship is fairly strong at $.44{ }^{38}$

Eighteen women ( $3.0 \%$ of the women) and 76 men (4.2\% of the men) identified themselves as members of visible minority groups by virtue of their colour or race.

Six women ( $1.0 \%$ of the women) and 26 men ( $1.4 \%$ of the men) considered themselves disadvantaged by reason of a persistent disability.

The men $(97.9 \%)$ were more likely than the women $(86.7 \%)$ to be working full time and not seeking part time work. Fifty-five women (9.3\% of the women who responded to the question) were working part time and not seeking full time, as compared to only 23 men $\left(1.3 \%\right.$ of the men). ${ }^{39}$ Seven women and eight men were working part time but seeking full time work.

A similar pattern existed in British Columbia, except that the greatest difference was for respondents who were $40-44$ years of age; $68 \%$ of the women and $90 \%$ of the men were living in a married or equivalent relationship, ibid. at 13.

35. The difference was even greater in British Columbia where $37.9 \%$ of the women and $63.2 \%$ of the men had children, ibid. at 14.

4. A similar pattern existed in British Columbia, except for those who were 45 years of age or older; $80 \%$ of the women and $85 \%$ of these men had children. ibid. at 15.

37. A similar difference existed in British Columbia where $13 \%$ of the women and $5 \%$ of the men who had children were living in a married or equivalent relationship, ibid. at 15.

3.. The chi-square is 15.967 and the significance level at $p<.(0) 1$. In British Columbia, $8.5 \%$ of the women and $1.2 \%$ of the men were working full time and not secking part time work. Brockman, Idenifying the Barriers, supra, note 6 at 17. 


\section{B. PERCEPTIONS OF GENDER BIAS OR DISCRIMINATION IN THE LEGAL PROFESSION}

Respondents were asked about their perception of the existence of gender bias or discrimination in the legal profession in Alberta (questions 34 and 35), and those who thought gender bias or discrimination existed were asked to identify the nature of that bias or discrimination (question 36). Table 3 shows that an overwhelming majority of the respondents in this survey $(97.2 \%$ of the women and $77.6 \%$ of the men) were of the view that there was some bias or discrimination against women in the legal profession; $25.3 \%$ of the women, as compared to $53.8 \%$ of the men, thought it was not widespread; $55.2 \%$ of the women, as compared to $19.6 \%$ of the men, thought it was widespread but subtle and difficult to detect: and $16.7 \%$ of the women, as compared to $4.1 \%$ of the men, thought it was widespread and readily apparent. ${ }^{\text {(1) }}$

With regard to gender bias or discrimination against men in the legal profession, $76.0 \%$ of the women and $55.1 \%$ of the men in this survey were of the opinion that there was none. Of the women respondents, $22.3 \%$ thought it was not widespread, as compared to $37.4 \%$ of the men. One women $(.2 \%)$ and 43 men $(2.4 \%)$ thought it was widespread but subtle and difficult to detect, and two woman $(.3 \%)$ and 36 men $(2.0 \%)$ thought that gender bias or discrimination against men was widespread and readily apparent."

\section{THE NATURE OF BIAS OR DISCRIMINATION AGAINST WOMEN}

Table 4 sets out the nature of gender bias or discrimination in the legal profession as reported by the respondents. This next part describes three areas which were identified as posing problems for women in the legal profession.

\section{Career Opportunities}

"Career advancement" was most frequently identified by both the women $(81.8 \%)$ and the men $(42.4 \%)$ who responded to this survey as an area in which women were discriminated against. ${ }^{+2}$ The next most frequently identified sphere in which women were discriminated against, cited by the women $(70.7 \%)$ and the men $(34.9 \%)$, was

A very similar pattern existed in the British Columbia survey where $97.5 \%$ of the women and $83.4 \%$ of the men thought there was some form of bias against women in the legal profession; $25.5 \%$ of the women and $52.6 \%$ of the men thought it was not widespreal; $58.4 \%$ of the women and $25.9 \%$ of the men thought it was widespread but subtle and difficult to detect; and $13.6 \%$ of the women and $4.9 \%$ of the men thought it was widespread and readily apparent. Supra, note 25 at 100.

In the British Columbia survey, $83.8 \%$ of the women and $64.7 \%$ of the men in this survey were of the opinion that there was no bias against men; $13.9 \%$ of the women and $31.2 \%$ of the men thought it was not widespread. Eight women $(1.1 \%)$ and seventeen men $(1.5 \%)$ thought it was widespread. but subtle and difficult to detect, and one woman $(.1 \%)$ and 12 men $(1.1 \%)$ thought that gender bias or discrimination against men was widespread and readily apparent, ibid. at 102.

12. Career advancement was identified as an area in which women are discriminated against by $75.5 \%$ of the women and $43.7 \%$ of the men in the British Columbia survey, ibid. at 104. 


\section{"attaining partnership." ${ }^{\text {43 }}$ Women made the following comments regarding career advancement and attaining partnership:}

- In the Provincial Attomey General's Department, Criminal Division, there are no women whatsoever in any administrative positions. In the Provincial Attorney General's Department, as a whole, there are only a few women who could be called managers or administrators and these are at a very low level.

- My experience is that firms like to hire men on the basis that they are more "dedicated" to the practice of law. That is, that men are prepared to try and attain high billable hours. In the law firm at which I practised women were originally paid at the same level as men (of equivalent experience) but did not enjoy the same pay raises even where their billable hours were equivalent and recovery of that time excellent. Further, the relatively small number of female partners decreased over time and what women partners there were were considered "light weights" in the partnership and were not part of the partners" decision making committee.

- The profession is still a "boy's club" where women are viewed as an expendable commodity. If cconomic times are tough, the women are the first to go. Often this can be justified on the basis of real or imagined factors: marketing skills, personality, commitment - all of which have a subtle element of gender bias. Specific measures are difficult.

- Career advancement, access to clients and partnership are subtle instances of gender bias; it is usually unintentional and attitudinal. It is not likely to change except through education, observation and a new generation of gender values.

-... Women are being hired now but they are not being promoted. They come into the legal profession as eager articling students starting at an even level with their male counterparts. However, as time goes on, men get involved on the better files and, if there is a shortage of work, get more files. In a couple of years, the men start getting paid more than the women becaluse they are doing better quality work and have more billable hours than the women who are not being involved on the same amount or quality of work. Many men also find themselves being let go with the comment that they have somehow "slipped between the cracks." It is my view that this discrimination is not intentional but that it is systemic and that women will continue to have problems until a conscious decision is made to make the extra effort to involve them.

One woman commented that men have a slightly better chance with regard to career advancement because billable hours were the criteria, while another said women and men had an equal chance because billings were the "bottom line test." One man commented that "ability to attract business [was] important" and another, that men had the advantage "because it is the woman who bears children." Another man commented:

- I think we are basically beyond the point where there is discrimination against women in Calgary law firms. I think without connections it's difficult to get hired. In the big firms, it seems that being a woman is an advantage.

43. Altaining partnership was identified as an area in which women were discriminated agains by $63.4 \%$ of the women and $32.1 \%$ of the men in the British Columbia survey, ibid. at 105. 
Question 27 asked respondents whether women or men had a better chance of professional advancement in their firm or organization; $46.0 \%$ of the women and $18.7 \%$ of the men reported that men have a much better or slightly better chance than women of professional advancement in their firm or organization. Only $23.3 \%$ of the women, as compared to $47.2 \%$ of the men, thought that women and men had an equal chance. ${ }^{44}$

Those in private practice were asked whether women or men had a better chance for partnership opportunities in their firm; $34.2 \%$ of the women and $15.8 \%$ of the men thought that men had a much better or slightly better chance with regard to partnership opportunities; $21.9 \%$ of the women and $44.6 \%$ of the men thought that women and men had an equal chance. ${ }^{45}$

Women respondents in private practice were twice as likely as the men to be associates or employees in a firm, and the men were almost twice as likely as the women to be partners. Some of this difference is expected, given the later entry of women into the legal profession. However, this is not the sole factor.

Table 5, which compares lawyers who are partners to all lawyers in private practice, shows that women were less likely than men to be partners among respondents in private practice within all call groups. Among respondents in private practice called before 1976 , $66.0 \%$ of the men and $54.5 \%$ of the women were partners. Among respondents called between $1976-1980,65.8 \%$ of the men and $60.0 \%$ of the women were partners. ${ }^{46}$ Only $35.3 \%$ of the women called between 1981 and 1985 were partners, as compared to $55.7 \%$ of the men. ${ }^{47}$ There was little difference between women and men who were called between 1986 and 1990 .

Only $21.0 \%$ of the women associates indicated that they would prefer to be partners, as compared to $44.4 \%$ of the men associates. This relationship between the gender of associates and their preferences regarding partnership remains even when controlling for years of call. ${ }^{48}$ However, it should be kept in mind that $72.2 \%$ of the women associates and $38.1 \%$ of the men associates identified "access to partnership" as an area in which women were discriminated against in the legal profession; and $45.3 \%$ of the women associates and $23.6 \%$ of the men associates thought that men had a much better or slightly better chance than women of becoming partners in their firm today. Similar patterns of

In the British Columbia survey, $41.1 \%$ of the women and $14.9 \%$ of the men reported that men had a much better or slightly better chance than women of professional advancement in their firm or organization; $29.4 \%$ of the women and $50.8 \%$ of men thought that women and men had an equal chance, ibid. at 104.

45. No similar question was asked in the British Columbia survey.

45. There were some variations in individual call years. For example, women in private practice who were called in 1979 were somewhat more likely than their male counterparts to be partners. $76.9 \%$ of the women as compared to $68.6 \%$ of the men.

47. There was one call year (1981) in which there was little difference between the women and men. $65.0 \%$ of the women and $66.7 \%$ of the men were partners.

4k. The zero order gamma of .50 shows a strong relationship between the gender of associates and their preference to be partners. The partial gamma of .50 indicates that there is no change when women and men associates are compared in similar call groups. 
perceptions existed among partners; $72.9 \%$ of the women partners and $36.7 \%$ of the men partners identified "access to partnership" as an area in which women were discriminated against in the legal profession; and $38.4 \%$ of the women partners and $17.8 \%$ of the men partners thought that men had a much better or slightly better chance than women of becoming partners in their firm today.

There was little difference between the 102 women and 697 men partners who reported how long they had practised prior to becoming partners. The median number of years for both women and men was the same ( 5 years), as was the mean number of years (4.7 years). ${ }^{49}$

There are a number of factors which might affect women's career advancement. For example, "other lawyers not giving appropriate weight to opinions" was identified by $59.7 \%$ of the women and $20.6 \%$ of the men as a form of bias against women. ${ }^{50}$

"Access to clients" was reported by $57.5 \%$ of the women and $25.3 \%$ of the men as a sphere in which women were discriminated against. ${ }^{51}$ Two men and one woman wrote that the bias was due to client preference. Two women wrote opposing views:

- There is a sexual bias in our firm. The women are not given the same "benefit of the doubt" as the men. Last year there were 2 lawyers in the firm who were not performing due to lack of work. One was a man, the other a woman. The man was introduced to lucrative clients and a busy lawyer "took him under his wing." The woman was left to fend for herself and ended up leaving against her will. None of this is overt -it takes a long time to realize. Women in the firm will go without a secretary longer than a man will. One of the women is an excellent [type of law] lawyer who does not receive any encouragement from the partnership. Men who are not doing very well in terms of client development receive introductions. support and files from the partnership.

- Gender biats does exist against men i.e. ...as a woman partner I may favour women associates in the sense of giving her work if I perceive she is not getting a fair load of work or quality of work from others. i.e. I pick the woman over an equivalent male associate.

"Assignment of files" was identified by $54.5 \%$ of the women and $18.4 \%$ of the men as an area in which women were discriminated against in the legal profession. ${ }^{52}$ One woman wrote that women were allocated "to less attractive areas of practice that are not as lucrative." A man who worked in the corporate commercial field wrote that there was bias against men in "doling out work in family law areas to women." One woman commented:

The median number of years was also 5 for both women and men in the British Columbia survey. The mean was 4.7 years for women and 4.3 for men. See Brockman, Identifying Barriers, supra, note 6 at 22.

5). In the British Columbia survey. $48.1 \%$ of the women and $21.9 \%$ of the men identified this as a form of discrimination against women. Supra. note 25 at 103.

51. In the British Columbia survey. $48.5 \%$ of the women and $25.3 \%$ of the men identified "access to clients" as a sphere in which women were discriminated against, ibid. at 110.

52. In the British Columbia survey, $42.5 \%$ of the women and $18.4 \%$ of the men identified "assignment of files" as an area in which women were discriminated against, ibid. 
-...I noticed another kind of discrimination against women; i.c. allocation of work of a complex and/or income generating nature going primarily to men. The effect is that the women who are and have been here are/have been the lowest billers. and because income and parnership prospects are based on the amount of money a lawyer brings in. women have been paid less than men at comparable levels after the first few years and rarely get into a position where partnership is offered.

The other woman and I both brought the above described discrepancy to the attention of one of the managing partners who in turn passed it on to another managing partner. We, individually. said we did not believe that the partners were actively discriminating against women in an intentional way but that the good work tended to go to the men if the client was a high paying lirm client because the partners were more comfortable working with men. We did not receive any acknowledgement from the partners that our assessment was correct and, indeed, the response was one of astonishment - a surprising response in that: I. records of each associates' input in dollars and hours are provided on a monthly basis and women are inevitably the low performers; 2 . although the firm has been around for a long time it has had only a couple of women partners most of whom left... due to lack of referrals of work (although referrals of work from male partners to male partner was/is not unusual); 3 . all the women who have been here have been very career rather than mainly family oriented, as capable as the men and as willing to put in the hours and personal life sacrifices.

"Judicial attitudes" were identified by $54.5 \%$ of the women and $21.7 \%$ of the men as a field in which women were discriminated against in the legal profession. ${ }^{53}$ One man commented that "this is where there is probably the most bias." Other men wrote:

- The large majority of gender bjas I have seen comes from male members of the bar that have been called for more than 10 years and from judges...

The judges are the worst in the sense that they are almost embarrassingly patronizing with female barristers. I've actually heard a judge call a young barrister "Missy". in the last year! There are several who I am sure see no place for females at the bar. I had another confide to me. in the wee hours of a social event. he was sure that one female lawyer present had to be a "dyke." As it happens she is a

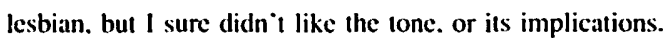

- Judges show that there is definitely a common advantage as against a male lawyer ir the other side is a female lawyer.

- General patronizing attitudes from dinosaurs at bar and bench.

"Hiring" was reported as an area in which women were discriminated against by $54.2 \%$ of the women and $24.2 \%$ of the men. ${ }^{54}$ Questions 25 and 26 asked respondents who were practising law whether women or men had a better chance of being hired as articling students and as lawyers in their firm or organization. The women respondents $(17.2 \%)$ were somewhat more likely than the men $(10.6 \%)$ to believe that men had a much better or slightly better chance than women of being hired as articling students in their firm or 
organization. Over a third of the women (38.2\%) and close to one-half of the men $(49.5 \%)$ thought that women and men had an equal chance of being hired. ${ }^{55}$

Women $(26.8 \%)$ were more likely than men $(15.9 \%)$ to report that men had a much better or slightly better chance than women of being hired as lawyers in their firm or organization. Women and men had an equal chance of being hired according to $37.2 \%$ of the women and $52.1 \%$ of the men. ${ }^{56}$

"Access to managerial positions" was seen by $52.8 \%$ of the women and $17.5 \%$ of the men as a sphere in which women were discriminated against. ${ }^{57}$

"Remuneration" was reported by $51.0 \%$ of the women and $14.2 \%$ of the men in this survey as an area in which women faced discrimination. ${ }^{38}$ Table 6 shows the pre-tax income from employment of respondents who were working full time, by year of call. The overall mean income for women was $\$ 63,518$ per year, as compared to $\$ 94,314$ for the men. The median incomes were $\$ 55,500$ and $\$ 77,000$ per year, respectively. Measured by both mean and median, the men in this survey earned more than the women in every call year, except for those called in 1990-91. Generally, the difference between women and men was much greater for those called prior to 1985 than for those called in 1985 or later. ${ }^{59}$

Women $(41.8 \%)$ were much more likely than the men $(9.8 \%)$ to identify the nature of promotional functions as a field in which women were discriminated against, and $40.5 \%$ of the women and $9.5 \%$ of the men identified office functions as such. ${ }^{(x)}$ Women made the following comments: "usually day time functions only"; "men more likely to be invited to hockey games with clients"; "sports" and "office social occasions - very allmale sports oriented (hockey, golf weekends - no women allowed!)."

\section{Combining Careers, Children and Chores}

In British Columbia, $17.6 \%$ of the women and $9.8 \%$ of the men believed that men had a much better or slightly better chance than women of being hired as articled students in their firm or organization; $35.6 \%$ of the women and $48.0 \%$ of the men thought that women and men had an equal chance of being hired, ihid. at 105-06.

In the British Columbia survey. $27.7 \%$ of the women and $18.0 \%$ of the men thought that men had a much better or slightly better chance than women of being hired as lawyers in their firm or organization, and $40.5 \%$ of the women and $51.6 \%$ thought they had an equal chance, ibid. at 109 . In the British Columbia survey, $45.5 \%$ of the women and $15.4 \%$ of the men were of the view that "access to managerial positions" was a sphere in which women were discriminated against, ibid. at 103.

5x. In the British Columbia survey. $51.2 \%$ of the women and $18.7 \%$ of the men were of the view that "remuneration" was an area in which women were discriminated against, ibill.

59. The British Columbia questionnaire gave categories of income for the respondents to check, rather than asking respondents for their income to the nearest $\$ 1000$. There was a somewhat similar trend to a wider gap in income after six years of call. See Brockman, Identifying the Barriers, supra, note 6 at 24.

These questions were nol asked in the British Columbia survey. 
Children undoubtedly have an impact on the lives of their parents, and the impact is generally greater for women than for men. Lawyers are no exception. Respondents were asked (question 59) whether child care responsibilities affected their career decisions regarding choices of jobs, specialities, and cases, and the hours they worked. Child care responsibilities had the greatest impact on respondents' hours of work; $80.7 \%$ of the women and $43.6 \%$ of the men checked 5-7 on a scale of $1=$ no effect to $7=$ a great deal of effect. The median response was 6 for the women and 4 for the men. Child care responsibilities had an effect on "choice of job" for $61.9 \%$ of the women but only $18.2 \%$ of the men. Such responsibilities also had an effect on "choice of speciality" for $34.2 \%$ of the women but only $7.9 \%$ of the men, and on "choice of cases" for $33.3 \%$ of the women but only $6.1 \%$ of the men."1

Questions 57 and 58 asked respondents who had children requiring care, about such care. ${ }^{62}$ Women respondents who were working full time provided a median of $40 \%$ of the time required to care for their children, as compared to a median of $25 \%$ provided by the men. ${ }^{63}$ Women respondents received a median of only $20 \%$ of the time required to care for children from the persons with whom they lived, as compared to a median of $66 \%$ received by the men from the persons with whom they lived. ${ }^{64}$

Respondents were asked how much time they spent on child care (including feeding, supervision, attendance at sporting and school events, etc). Women respondents, who worked full time and had children requiring care, spent over twice as much time on caring for children than the men. These women $(\mathrm{N}=191)$ spent a median of 35.0 hours (mean $=34.7$ hours) a week on such care while the men $(\mathrm{N}=941)$ spent a median of 15 hours (mean $=17.0$ hours). ${ }^{65}$ The women spent a median of 10 hours a week on household chores, as compared to the men who spent a median of 8 hours a week. ${ }^{66}$

Women who combine children and careers have been referred to in the literature as "superwomen"67 or to taking an "integrated" approach to their lives. ${ }^{68}$ In order to

i.1. No similar questions were asked in the British Columbia survey.

62. Only $38.5 \%$ of the women working full time. as compared to $57.3 \%$ of the men, indicated they had children who required care.

63. In the British Columbia survey, women respondents who worked full time provided a median of $40 \%$ of the time required to care for their children, as compared to a median of $20 \%$ provided by the men. supra, note 25 at 126.

(w. In the British Columbia survey, women respondents received a median of $20 \%$ of the lime required to care for their children from the persons with whom they lived, as compared to a median of $66 \%$ received by the men from the persons with whom they lived, ibid. at 126.

os. In the British Columbia survey, women spent a median of 30.5 hours a week on such care. and the men spent a median of 14 hours, ihid. at 126-27.

66. The medians for women and men in the British Columbia survey were the same as they were in the Alberta survey, ihid.

67. See for example. L.H. Schafran. "Eve. Mary, Superwoman: How Stereotypes About Women Influence Judges" (1985) 24 Judges J. 12.

ax. V.G. Drachman. "'My 'Partner' in Law and Life': Marriage in the Lives of Women Lawyers in Late 19th and early 20th Century Amcrica" (1989) 14 Law and Social Inquiry 221 examined the way women lawyers dealt with marriage or non-marriage and their careers in the late 19th century and early 20 th century. She identified three distinct sets of attitudes towards career and marriage which still exist today (although the focus today may have shifted from marriage to children): a) the 
identify any superwomen (or supermen) amongst the respondents, the number of hours they spent on paid work, household chores, and child care were added together. Using the criterion of 100 hours or more per week, $15.1 \%$ of the women and $5.3 \%$ of the men who responded to this survey fell into this category. ${ }^{69}$ If one uses the criterion of 80 hours or more a week, $33.3 \%$ of the women respondents and $24.0 \%$ of the men qualify for the "super" label. ${ }^{70}$ Overall, the women worked a median of 68 hours, and the men worked a median of 65 hours per week on paid work, household chores, and child care. ${ }^{71}$

Question 61 asked respondents who had become parents since 1985 whether they had experienced any of thirteen different consequences (and invited them to list additional consequences). Thirty-one percent of the women and $29 \%$ of the men respondents in this survey had children since 1985. Table 7 sets out the percentage of women and men who experienced each of the suggested consequences. "Stress from competing demands" was the most common consequence experienced by both the women $(77.3 \%)$ and the men $(54.6 \%)$. One man put five check marks beside his response. "Loss of income" was the second most frequent consequence experienced by women $(50.8 \%)$, followed by "testing of commitment to work" (47.0\%), "pressure to return to work during parental leave" $(41.1 \%)$, "pressure to work while on parental leave" $(35.7 \%)$, "difficulty in obtaining flexible hours or part time work" (27.6\%), "delay in promotion" (23.8\%), "unreasonable work load following parental leave" (17.8\%), "loss of seniority" (15.7\%), "loss of clients" $(15.7 \%)$, "difficulty in obtaining leave" (10.8\%), "loss of job" (10.3\%), and "loss of office space" $(5.9 \%)$.

Two women wrote that the pressure to return to work was financial pressure. One woman wrote that her loss of clients "was minimal, but some were not prepared to wait out maternity leave or reduced work." Other results mentioned by women included: "loss of secretary"; "initial lack of internal referrals of work - left to generate my own work"; "loss of options"; "loss of files"; "loss of credibility, change of attitude towards me, comments behind my back about my 'hours of work'"; "difficult returning to the work force"; and "a change in my hours and mode of work necessitaled by having two children." Other women wrote:

- Bcing "self-employed" in a small partnership meant I had control over how much leave to take and how much money to lose.

- I wats on contract with a corporation when I became pregnant - they would not guarantee my position while I was on maternity leave. so I took a new one. This area is very problematic!! The corporation wanled me to work at home during leave!

separatists" approach, in which women must remain single to practice law, b) the Victorian approach, which holds that women must modify their careers to accommodate the demands of marriage, and c) the integrated approach. which is that women can do both. In the British Columbia survey. $10.8 \%$ of the women and $4.7 \%$ of the men fell into this category, supra, note 25 at 128.

In the British Columbia survey. 21.1\% of the women and $14.0 \%$ of the men fell into this category. ihid. at 128 .

In the British Columbia survey, women worked a median of 62 hours a week, men a median of 65 hours a week, ibid. at 128. 
One woman who chose to leave work and stay at home was from a supportive firm, yet another quit because of "unreasonable expectations" from her employer. Another women went from private practice to teaching, and another avoided all of these problems by working for a corporation.

For men, after "stress from competing demands" (54.6\%), "testing of commitment" was the most frequent consequence experienced (16.3\%) followed by "loss of income" $(8.8 \%)$, "difficulty in obtaining flexible hours or part time work" (3.7\%), and "difficulty in obtaining leave" $(3.1 \%)$. The other consequences were experienced by less than $2 \%$ of the men who became parents since 1985 .

Other consequences reported by men included: "no personal time"; "no parental leave, demands of clients"; "prestige and satisfaction"; "pressure to go home during work"; "difficult to take time off as sole practitioner"; "loss of sleep"; "loss of free time - I used to exercise 4-5 times a week - now not at all"; "marital difficulties"; and "great joy!"

Including those respondents who indicated that a particular bias exists against both women and men, the third most frequent category of discrimination against women, according to women $(64.6 \%)$ was "lack of accommodation for family commitments." Only $22.3 \%$ of the men viewed this as a form of bias or discrimination against women. ${ }^{22}$

This lack of accommodation might take a number of different forms: lack of flexibility in work schedules, problems with parental leave or lack of such leaves, etc. Table 8 presents the percentage of women and men who reported the availability of specified benefits at their place of work, out of the total number who responded to the question and did not indicate that the benefits were "not applicable" to their work place. ${ }^{73}$

The flexibility to work part time was offered by firms or employers where $36.5 \%$ of the women and $30.6 \%$ of the men worked. One woman, who had worked part time earlier in her career, wrote: "it was part of my arrangement. My office has said they would not offer it in the future." Another wrote:

\footnotetext{
- The reason I chose to leave the corporation I had been working for for 10 years was due to the inability to provide: 1. part time work: 2. flexible working hours: 3. job sharing: which I believe were necessary to facilitate child care. Although the clients I am now performing work for. for the main part are not interested in part time work, I hope to eventually find a small corporation to enable me to work part time.
}

Flexible work hours within a full time position were available to lawyers where $52.1 \%$ of the women and $58.0 \%$ of the men worked. "Job sharing" was reported by $16.1 \%$ of

72. In the British Columbia survey, $68.4 \%$ of the women and $33.8 \%$ of the men were of the view that this was a form of bias against women, ibid. at 119.

73. By not including the number who responded "not applicable" in the calculation these figures might actually exaggerate the extent to which benefits are available. However, to have included those who indicated "not applicable" in the calculation, the figures might have diluted the extent to which these benefits are available. 
the women and $18.2 \%$ of the men. The availability of part-time partnerships was reported by $6.3 \%$ of the women, and $5.3 \%$ of the men. One man, who worked as a partner, wrote that part time partnerships "would be nice."

\section{Other comments by women included:}

- I have been told outright that one cannot be a part-time partner, yet I know that many male partners are just that, in fact, it just hasn't been openly called by that name. Taking time away from practice to golf. sit on committees, pursue political interests is quite acceptable, presumably under the guise of "marketing." Taking time for one's family is a disgraceful thing and must be hidden. One man I know would say he was going to a meeting, rather than admit he was picking up his daughter from the nursery school. Why? He didn't want to hurt his chances at partnership.

- I am a new lawyer and a relatively new mother. The greatest problem I have had with practising law (although I am quite happy with my new position) is the expectation that I at least presend to have no family commitments. I articled at |lirm| and my commitment to the job was challenged even though I billed the average number of hours while coping with an infant and nursing. 10 boot. I needed a wife. but instead 1 only had a husband. At least childless women can nurture themselves. The expected norm for behaviour is to behave like a single man - a norm that falls apart once women have kids and which is unhealthy in the first place. I consider myself a very capable lawyer, but I have had to make choices (mostly financial) simply because the practice of law in a major law firm is fundamentally psychologically unhealthy. I intend to live happily until I'm 100 years old, not drop dead rich at 50.

- There is a more suble form of hias which rewards "macho" behaviour. For example, it's a badge of honour for lawyers to work all night, or 18 hours a day, etc. - this supposedly shows true mettle. With a family, you cannot earn the brownic points - even if you wanted to (personally I think working all night is inefficient and ends up needlessly inflating a client's bill).

- I believe there's undoubtedly some bias against women but I also believe that part of that bias stems from the fact that many women are not prepared to accept prevailing working terms and conditions and that they want to change them to accommodate family commitments or otherwise achieve a better quality of life. While family commitments and a better quality of life are obviously very important considerations which are, I believe, becoming increasingly important to a larger number of people, nevertheless, measures to accommodate these wishes (such as flex time, job sharing, part time work and, last but not least, a decent number of working hours) can all cost an employer additional money and inconvenience. So long as there are potential partners. employees, etc. who are prepared to work to the "normal" rules, I expect employers and law firms will tend to continue to hire and promote people whom they believe will be the most likely to conform to those rules.

- It is no accident that a majority of the successful women in large firms are not married and often do not have children. It is not solely as a result of legal abilities, broadly defined, that the number of women in larger partnerships is not appreciably increasing. Identifying specific instances of bias is usually hard.

- In my own experience. I had no further referrals or work assignments from the senior partner in my work group after the day I told him I was pregnant. I had until that time, been his right hand on a majority of his practice. Four months after my short leave I was told I did not have a future with the firm, after being assured for three years that I was partner material. Was there bias? 
Men commented: "women may have different priorities, e.g. children"; "women have babies"; and,

- I have fell a bias exists in favour of female lawyers with children in assignment of work. The needs of their children at times conflict with their case load and there seems to be more flexibility given to them in rejecting assignments than to males. The perception seems to be that females are primary caregivers and males are not and therefore females get "special treatment."

- Law and families are a tough combination. Women do suffer more than men from this phenomenon.

Although child care in the work place is a growing phenomenon in corporations, ${ }^{74}$ only $1.7 \%$ of the women respondents and $2.1 \%$ of the men reported that it was offered to lawyers by their firm or employer. None of the respondents elaborated on the nature of the child care which was available. A recent child care initiative for lawyers only in downtown Montreal will provide extended hours for lawyers who work late. It claims to be the first of its kind in Canada and the United States. The president of Montreal's young lawyers association is of the view that a "happy young lawyer is not a lawyer who works 2,400 billable hours a year. A happy lawyer can take care of his [sic] children..." ${ }^{.75}$

Maternity and paternity leave policies are not easily canvassed in a mail-out questionnaire. Many of the respondents did not know whether their firm or employer offered such benefits, and those who did, often qualified their responses. In many instances the question had never come up and, therefore was never addressed. The comments also indicated that maternity and paternity "policies" are to some extent "flexible," "ad hoc," "negotiated" on an individual basis, provided "as circumstances require," "discretionary, [with] no specified period - considered on application and circumstances," "as much as the doctor suggests," etc. There are arrangements where compensation to partners is "unlimited, i.e., directly dependent on fees billed and collected." There are also policies presently being negotiated.

Keeping these comments and limitations in mind, Table 8 shows the extent to which such leaves were available from the respondents' firms or employers. Unpaid maternity leave for partners was more available where the women respondents worked $(48.3 \%)$ than where the men worked (37.9\%). A median of 12 weeks leave was reported by the 63 women and the 177 men who reported the length of such leave. Similarly, unpaid maternity leave for associates or employees was more available where the women respondents worked $(61.9 \%)$ than where the men $(46.2 \%)$ worked. The 168 women who responded to the question reported a median of 18 weeks leave while the 256 men

See for example, J. Lanthier, "Korporale Kid Kare: Day Care Costs Plenty, but Companies Provide it to Promote Efficiency and Employee Goodwill" Financial Post (8 May 1989) 17; M. Cu-Uy-Gam, "More Firms Find Child Care Solutions to Keep Their Staff" Financial Post (27 November 1989) 31; and M. Stanisby, "Babies in the Boardroom" Vancouver Sun (9 December 1989) El. 
reported a median leave of 16 weeks. Unpaid maternity leave for contract lawyers was reported by $25.3 \%$ of the women and $18.3 \%$ of the men. The median leave reported by the women $(\mathrm{N}=26)$ was 22 weeks, and the men $(\mathrm{N}=63)$ reported 16 weeks.

Unpaid paternity leave for partners was available where $9.2 \%$ of the women worked and where $8.0 \%$ of the men worked. The women $(\mathrm{N}=12)$ and men $(\mathrm{N}=26)$ reported a leave of 12 weeks. Unpaid paternity leave for associates and employees was available where $13.7 \%$ of the women worked and where $9.6 \%$ of the men worked. The women $(\mathrm{N}=26)$ reported 12 wecks and the men $(\mathrm{N}=41)$ reported 17 weeks. Unpaid paternity leave for contract lawyers was available where $5.9 \%$ of the women worked and where $4.4 \%$ of the men worked. A median of 12 weeks existed where both the women $(\mathrm{N}=9)$ and the men $(\mathrm{N}=11)$ worked.

Paid maternity leave for partners was available where $32.2 \%$ of the women worked and where $29.8 \%$ of the men worked. A median of 12 weeks existed where both the women $(\mathrm{N}=66)$ and the men $(\mathrm{N}=176)$ worked. Paid maternity leave for associates and employees was available where $32.9 \%$ of the women worked and where $29.5 \%$ of the men worked. A median of 12 wecks (in addition to Unemployment Insurance benefits) existed where both the women $(\mathrm{N}=91)$ and the men $(\mathrm{N}=173)$ worked. Paid maternity leave for contract lawyers was available where $8.4 \%$ of the women worked and where $8.8 \%$ of the men worked. A median of 12 weeks existed where both the women $(\mathrm{N}=11)$ and the men $(\mathrm{N}=33)$ worked.

Paid paternity leave for partners was available where $2.7 \%$ of the women worked and where $3.1 \%$ of the men worked. For associates and employees it was available where $4.0 \%$ of the women worked and where $3.3 \%$ of the men worked. Paid paternity leave for contract lawyers was available where $2.0 \%$ of the women worked and where $1.3 \%$ of the men worked.

Questions 63 and 64 asked respondents who have had children since 1985 whether they had taken maternity or paternity leave when their last child was born, and if so, what percentage of their pre-leave income was covered by unemployment insurance, their firm, disability policies or other sources. The mean number of weeks taken by the women was 13.7 weeks: the median was 12 weeks. Four women indicated that they worked at home during their time off. The mean number of weeks taken by the men was .4 weeks, and $58.7 \%$ of the men had not taken any leave.

In terms of whether the leave time was sufficient, women reported a mean of 4.2 (median=4.0) on a scale of $1=$ very sufficient, $7=$ very insufficient, and men reported a mean of 4.3 (median $=4.0$ ). Almost half of the women $(49.1 \%)$ and men $(49.3 \%)$ checked 5-7 on the scale. A number of respondents commented on the sufficiency of their leave or the lack of it. One woman, who had taken six weeks off, indicated that she would take three months next lime. Other women wrote:

- As a parner. maximum maternity leave was 6 weeks, the maximum annual holiday time. I worked until the day before I delivered both children. I took 3 weeks leave with my first child, and 6 weeks with the 
second. The pressure to come back to work quickly was due to the fact that I was a partner and did not want to lose clients or had too big of a mess to come back to.

-...At 9 weeks the baby was 100 young to be without me. I am trying to continue breast feeding but the baby is supplemented more and more. There was quite a bit of consternation with management when I asked for a secluded spot to pump my breast milk at noon hour. I am tired. stressed. and cannot function well. It will take me longer to recover from the birth than I would if I had a 3 month leave.

Being a parent and a lawyer is very difficult. Clients are very accepting and congratulated me. Some did place their work elsewhere while I was gone and I'm not sure that I will get it all back...

- Having 12 weeks leave means you have 10 work until the day you deliver, if you want enough time after the birth to nurse the baby, and get back on your feet a bit before going back to work. It is exhausting, and a little bit harder with each child.

- I was away from work for three months. I intended to lake one week off before my child was bom, but my child was born on what was to be my last day of employment. I returned to work during maternity to complete a two day trial. This was largely my choice. as I felt that it was unfair to the client as the trial date had been set some time in advance and it would have been inappropriate for someone else to carry the trial.

I feel that my maternity leave was insufficient. When I returned to work I was still nursing my child and was waking up several times during the night to do this. I feel that the minimum maternity leave should be four months and preferably six months. My leave in fact, consisted of six weeks maternity leave, three weeks holidays and three weeks sick leave. Therefore, I was paid for six weeks of matternity leave.

- I was not ready to return and might have chosen not to do so however [due to economic circumstances] I had no choice but to return to work on a full time basis. But had I simply wished to extend my leave further (at that lime. statutory leave was 16 weeks and I had requested and been granted an additional 4 weeks - "special leave") I do not think my then current employer would have been amenable.

- I believe that a 3 month maternity leave is generally not sufficient especially if the child arrives later than expected or if there are complications involved in the birth. There is a great difference in maturity and "capabilities" of a 6 month old child vs a 3 month old child or even between a 4 month old child and a 3 month old child. My firm requested that I do some limited work during my maternity leave and requested that I come back to work a month or even two weeks early because at that time they were very busy.

- My firm has no maternity leave policy for lawyers. I felt I was expected to come back "soon" but I had a tolerant partner who let me set my own return date 114 weeks]. I wish I could have laken a year and returned on a part-time basis.

- Up until last year... the firm had a malernity policy of 9 weeks paid. If you wished to extend the leave you could (up to a maximum of 4 months) but you forfeited the 9 weeks paid. At 9 weeks you must return to full time work and take no holidays for 3 months. This was unilaterally (the partnership decided) revoked by changing the basis of pay from salary to percentage of billings in. It was still "okay" to take 9 weeks but there would be no payment at all. I was pregnamt when this decision was made. The 
firm knew this and I was told no exceptions would be made. I am now facing a dramatic and unforeseen salary cut.

I support my family... We decided to have another child and I would take the 9 weeks leave as I had no choice. What a choice: limiting our family or having a family under almost impossible conditions.

- My child was born during my bar admission course. LESA was very accommodating; however, I was only allowed to take off 2 weeks or else I had to split my articles. I returned to work when my child was 2 weeks old to complete the last two weeks of my articles.

This created extreme difficulty for UIC and I lost benefits for that time. I then had to study for my second set of exams which were scheduled for August. A job was offered to me by my employer which was to re-commence September 1.... Therefore, I could not write any supplemental exams as I was offered to be kept on where I articled on the condition that I be admitted to the bar by Sept 30...

Since the next supplementals were scheduled for November, I had to pass all exams. This caused much stress since I already had to study for the exams with a one month old baby. Since that time I have only taken two days holidays at Christmas. This has been an exhausting year.

\section{Two women in private practice wrote:}

- As a sole practitioner my maternity leave was: the day I delivered, the next day (Friday). Thank god it was a long weekend. The baby came to work with me for 2 hours on Tuesday. The rest of the month was part-time. Unfortunatcly I didn't have a choice as my sole practice was only 5 months old and I was extremely busy.

- Being in private practice for myself and in a cost sharing arrangement with others it was virtually impossible for me to take more time off. I would have been satisfied to have no income throughout a period of leave (i.e. I am not eligible for UIC maternity leave) but instead I had to cover all office costs, pay my secretary etc. throughout that period of time. I did try to find someone to run my practice but was not successful in finding someone who was competent to do so. Other women lawyers I know who did stop practice for a period to have a child found their practice significantly decreased upon their return. So I feel I made the right decision so far as my practice was concerned. I was able to find competent care for my children at this tender age of 3 weeks.

I am not sure there is an answer to this dilemma as a small private practice depends so much on the individual lawyer. It is not like another small business which can be run by a manager in the absence of the "owner."

One man commented that his leave was very insufficient because they had adopted a child while another wrote that he "would have liked to have spent more time with mom and child." Other men commented:

- While no one told me that I couldn't take more time off, nor in fact even implied that I couldn't take more time off. with respect to advancement in the firm and salary negotiation, nothing matters other than how much you can produce and by laking morc time off, I would have placed myself in an extremely difficult position with respect to my ability to generate income for our office sufficient to sustain any credibility in secking a wage increase, which obviously is very impontant when your spouse is not working and you are the sole "breadwinner" at a salary level that is already below what one would consider a reasonable level. 
- There were unusual circumstances involved following the birth of our last child. As a result, the answers to question 63 ought not to be given any weight in assessing the results of your survey.

- Had just started working for a new firm - not appropriate to take more leave at the time.

Of the 185 women who had children since $1985,125(67.6 \%)$ received payments from at least one source. Of these 125 women, 76 received some payment from unemployment insurance; nine of these 76 women received a "top up" payment from their firm which brought their total payments to $90 \%$ or more of their pre-leave income, two had payments from their firm which brought their income up to approximately $85 \%$ of their pre-leave income, and one had her income brought to $51 \%$ of her pre-leave income.

Forty of the 125 women received payments only from their firm. Most frequently this payment was $100 \%$, received by 31 of these women. Six women received between 50 $80 \%$, and three received $10-45 \%$ of their pre-leave income. The 31 women who received $100 \%$ of their pre-leave income from their firms had leaves which ranged from 2-18 weeks, with an average of 9.6 weeks (median $=11$ weeks). Mean satisfaction for these women was 4.7 (median=5.0) on a scale of $1=$ very sufficient, $7=$ very insufficient.

Eight of the women received payments ranging from $10-100 \%$ of their pre-leave income from disability insurance, and four women indicated that they had used vacation time for maternity leave.

There were 69 men who received payments while on parental leave. Sixty of them received $100 \%$ of their pre-leave income from their firm, and one received $25 \%$ from his firm. Eight men received $100 \%$ of their pre-leave income from other sources. Leave time for the 60 men who received $100 \%$ of their pre-leave income ranged from less than 1 week to 8 weeks. The average leave was 1.1 weeks (median=1 week). Eleven men indicated that they had used vacation time for leave and one man had taken an eight week sabbatical. Mean satisfaction with the sufficiency of such leaves was 3.6 (median=4.0).

A man commented, "anyone who works for him or her self cannot afford to take paternity/maternity leave", and a woman who had taken ten days off during law school suggested that law school "should be available to all on a part time basis."

\section{Sexual Harassment}

Sexual harassment exists in the legal profession. Of the women respondents, $57.7 \%$ identified unwanted teasing, jokes or comments of a sexual nature as an area in which women encountered discrimination in the legal profession, as compared to $25.3 \%$ of the men. ${ }^{76}$ Women commented: 
- Gender bias from male lawyers and male judges usually is paternalistic and is more common in males over 35 than under. Unwanted teasing. jokes or comments of a sexual nature were most common while 1 was pregnant.

Male colleagues think "you're just a woman - what do you know" comments are acceptable teasing.

- Both men and women are subjected to "unwanted comments of a sexual nature" in the work place any crass comment falls in this category. Unfortunately in using these more neutral words in the questionnaire, it includes a lot of off the cuff comments - c.g. comments re "balls", sexual swear words which may be "unwanted" but are more offensive to women than to men at times.

- The instances of unwanted sexual advances and unwanted teasing. jokes or comments of a sexual nature were relatively rare.

\section{A man commented:}

- The gender bias I have seen comes from older men in the form of naughty jokes, and unwanted touching (versus pawing). Examples are a senior lawyer insisting on giving his secretary a neck massage. when she was obviously discomforted by it. Or the more usual case of a senior male lawyer, recently divorced and drunk, "hitting" upon staff at social events, and regretting it in the morning.

Unwanted sexual advances were reported by $37.0 \%$ of the women and $17.2 \%$ of the men as an area in which women were discriminated against women in the legal profession. One woman wrote, "attend an Edmonton Bar Xmas party!!" A man wrote that unwanted sexual advances occurred towards women "even by provincial court judges."

Table 9 shows the frequency with which respondents who were practising law personally observed or experienced types of sexual harassment in professional settings in the last two years. Almost one third of the women $(31.5 \%)$ and $6.9 \%$ of the men had observed or experienced women lawyers being subjected to unwanted sexual advances by other lawyers. Such behaviour was observed or experienced more than five times in the last two years by $5.8 \%$ of the women and $.7 \%$ of the men. The same type of behaviour, directed at women lawyers by clients, was observed or experienced at least once in the last two years by $34.6 \%$ of the women and $8.2 \%$ of the men.

"Women lawyers subjected to teasing, jokes or comments of a sexual nature by other lawyers" was personally observed or experienced by $64.7 \%$ of the women and $32.1 \%$ of the men. This behaviour was observed or experienced more than five times in the last two years by $32.4 \%$ of the women and $6.6 \%$ of the men. Such behaviour by clients towards women lawyers was observed or experienced at least once in the last two years by $51.5 \%$ of the women and $18.2 \%$ of the men.

"Support staff subjected to unwanted sexual advances by lawyers" was reported by $22.7 \%$ of the women and $13.4 \%$ of the men. According to $20.8 \%$ of the women and $14.5 \%$ of the men, support staff were observed being subjected to this behaviour by clients. "Support staff subjected to unwanted teasing, jokes or comments of a sexual nature by lawyers" was reported by $43.0 \%$ of the women and $25.6 \%$ of the men. Such 
behaviour by clients towards support staff was observed by $30.9 \%$ of the women and $20.8 \%$ of the men.

Question 24 also asked whether respondents had observed men lawyers being subjected to unwanted sexual advances, teasing etc. ${ }^{77}$ Only $2.6 \%$ of the women and $3.5 \%$ of the men reported men lawyers being subjected to unwanted sexual advances by other lawyers. According to $7.5 \%$ of the women and $7.3 \%$ of the men, men lawyers were observed being subjected to this behaviour by clients. Men lawyers being subjected to unwanted teasing, jokes or comments of a sexual nature by other lawyers was reported by $22.0 \%$ of the women and $18.9 \%$ of the men. Such behaviour by clients towards men lawyers was observed by $10.9 \%$ of the women and $10.8 \%$ of the men.

One woman and six men wrote comments in the margin to indicate they had difficulty determining whether the behaviour they observed was "unwanted." One woman commented that she found the jokes amusing, and others wrote:

- One of the "subtle" discriminations against women has been the conversations of male lawyers during coffec. drinks and social functions. On the vast majority of these occasions. conversations revolve around sports and sexist remarks, neither of which female lawyers have any interest in participating.

- The only other incident of note occurred a few years ago at a Chambers Application. Both clients were present and the court sent us all down to the cafeteria to sort out some access arrangements. As my client and I were getting our coffee someone came up behind me and put an arm around my waist. I was astounded and turned to discover opposing counsel, whom I had not met until that day. My client looked a bit surprised and not too happy. I think opposing counsel did this to demean me in front of my client or make her think that she could not trust me in this very bitter dispute. For months after I thought about explaining to the client what had occurred, but in the end I did not do so as the whole incident was pretty boring and stupid.

- I have been asked to share accommodation and how I would explain it to his wife (If seconding a trial [out-of-town]). I have overheard conversations relating to strategies to keep women out. I have been told I am too attractive to be taken seriously. . . I am routinely treated as a "sweet young thing" at social functions. I went to school longer than most of my fellow gradualcs. . Joking around is fine but sex is not a job consideration. Whether I marry or not is my business and why should I have to be held back because I might. I am single and have been doing it on my own. I never asked for a free ride. I have been literally attacked physically by a male lawyer. I got sick of interviews that related more to dating than to law. Their sexual problems with their ex-wives were not one of my concerns or questions about the job.

There is some question as to whether men can experience "sexual harassment" in the same way that it is experienced by women. Women experience sexual harassment in the context of potential violence: Presentation by L.C. Smith "Sexual Harassment in the Workplace" (March. 1991) in Employment Law: Human Rights in the Workplace (Vancouver: The Continuing Legal Education Society of British Columbia, March 13, 1991). Even women in positions of power can be sexually harassed by men with less power, because "gender power, or male power, in our society often overrides the kind of power that women may have within the institution": Comment by Professor J. Osborne, Simon Fraser's Harassment Policy Coordinator in Simon Fraser Week (7 March 1991) at 2-3. 
- I have worked both for 2 small firms with roughly the same or close to the same number of men and women and now work for a [10-19] lawyer firm of whom only 2 are women. I noticed no discrimination on the basis of sex in the small firms but very quickly after joining the larger firm noticed different treatment of women, mainly in the nature of "friendly" sexist jokes, inappropriate comments, etc., which would have been considered inappropriate and not even funny in the smaller, more balanced (malefemale??) firms.

\section{Comments from men included:}

- I haven't seen it unwanted. If restricted to teasing, etc. it offers relief through the day and a smile.

- Unwanted but unoffensive in firm.

- [sexual advances by clients to support staff] these are polite but unwanted requests for dates!

- Imen lawyers subjected to unwanted teasing . . . ] thousands, part of daily exchange of ideas.

- An area not discussed in the survey is the difficulty experienced by male lawyers due to sexual advances and teasing, jokes and comments of a sexual nature usually directed at them from support staff and secretaries.

Societal norms make it somewhat easier for men to deal with these situations than for women, but nevertheless it can become a serious problem. A man is expected to allow all the jokes and advances to occur yet if he ever allowed an advance to progress he is seen as taking advantage of a vulnerable staff member. Because of the inequality in power and position, the staff members are certainly more vulnerable than are the male lawyers. This does not though, change the fact that many staff members make advances on the male lawyers. I have personally experienced this and am aware of many other lawyers in the firm who have also experienced problems.

There are situations where the lawyer welcomes and/or initiates the advance and that is of course unacceptable behaviour, but the number of unsolicited, unwanted advances by staff members to the male lawyers continues to astound me. This makes firm functions particularly difficult to enjoy, as male lawyers try to avoid those staff members who have "designs" on them. in an effort to avoid problems for their wife and family or girlfriend. The situation can become even more unpalatable when firm "family" events are held.

Men are fortunate in that this difficulty does not generally inhibit career objectives or advancement for them as it often can for women. Despite this thought, it is a problem which should be identified and to which some attention should be paid in the future. Male lawyers need to learn how to avoid uncomfortable situations and staff members need to realize that some behaviour is simply inappropriate in work related situations. This is certainly not a problem as significant as those facing women due to discrimination in the workplace, but it may be something which can somehow be dealt with to make the workplace easier for all to be part of.

\section{THE NATURE OF BIAS OR DISCRIMINATION AGAINST MEN}

As is shown in Table $3,76.0 \%$ of the women and $55.1 \%$ of the men thought there was no bias or discrimination against men in the legal profession. Most of those who thought there was bias thought that it was not widespread. "Judicial appointments" was most frequently identified as an area in which men encountered discrimination. It was identified 
by $26.3 \%$ of the men and by $11.3 \%$ of the women in this survey $(16.5 \%$ of the women and $3.1 \%$ of the men were of the view that women are discriminated against in the legal profession when it comes to judicial appointments). ${ }^{78}$ Six women and 30 men commented that gender bias exists against men in recent judicial appointments. Comments, the first two by women and the rest by men, included:

- The current trend to appoint women to the bench evidences a bias against men. However, until there is an appropriate proportion of women judges and justices this bias is a necessary one.

- Judicial appointments - active and public programs to increase female representation immediately give rise to questions of competence. Such programs do not necessarily achieve the intended objective.

- Many qualified men being overlooked - look at last 12 Q.B. appoinıments.

- [5 check marks] If I could come back as a paraplegic native female I would be appointed to the bench immediately.

- Women are now able to secure judicial appointments because we have some "catching up" to do.

- While I have indicated I prefer to be a judge, realistically I do not expect this to happen (though I am on the short list for a Provincial Court appointment, or so I have been told). I have been told by several members of the bench (including a female) that I cannot expect to be appointed as the government has decided that "sexual balance" on the bench is a priority. It was suggested (humorously) that I contemplate a sex change operation or acquire a disability, in which case I would be eminently qualified.

- More woman are being appointed as judges to offset the past male domination.

- [Judicial appointments as discrimination against men - - at least for the short term until ratio is balanced.

- [Judicial appointments as discrimination against men is] perceived more than actual.

The next most frequently identified area in which men were discriminated against, cited by $11.1 \%$ of the men and $15.0 \%$ of the women, was "lack of accommodation for family commitments." ${ }^{179}$ Two women and one man commented on the lack of accommodation in the legal profession for men:

- Men are limited in their ability to undertake family responsibilities.

In the British Columbia survey. "judicial appointments" was also the most frequently identified area in which men were discriminated against, identified by $22.9 \%$ of the men and $10.6 \%$ of the women in the survey $(17.1 \%$ of the women and $4.6 \%$ of the men were of the view that this was an area in which women were discriminated against, supra. note 25 at 103).

77. This includes those respondents who indicated there is bias or discrimination against both women and men when in this regard. 
- I do not believe that there is widespread gender bias or discrimination against men in the legal profession, but I do feel that men who would like to spend more time with their families, would not be given the same opportunities that women are given. I do not think that this is restricted to the practice of law, but is a common problem throughout society in general.

- [There is| I. lack of flexibility regarding "balance" of life and practice, 2. lack of opportunity to practise part time or with a reduced job load. 3. requirement to develop and maintain own practice as opposed to servicing firm clients i.c. male lawyers must be competent and develop business, most female lawyers are not expected to market and develop business to the same extent.

Other areas in which men encountered bias or discrimination were reported by under $5 \%$ of the women and men who responded to this survey.

\section{E. DENIAL OF OPPORTUNITIES ON THE BASIS OF GENDER}

Tables 10 and 11 show substantial differences between the women and the men when it comes to having been denied an opportunity to work on a file because a client or another lawyer preferred a lawyer of the opposite gender. In the last five years, $49.7 \%$ of the women, but only $14.2 \%$ of the men, were denied an opportunity to work on a file because a client preferred a lawyer of the opposite gender. ${ }^{80}$ This experience happened "often" or "sometimes" to $29.7 \%$ of the women and $3.5 \%$ of the men. One women stated that "men in construction prefer to deal with men," and another stated that "banks prefer male lawyers, as do criminal law clients." Other women wrote:

- I do family law in a large firm. I practise in a no nonsense way and insist on being paid. My partners used to refer work to me. A few male client referrals came through. The male clients in a few instances were difficult and chauvinistic. I had some difficulties with one client in particular who refused to take my instructions and whom I eventually fired. He also felt (as did other "big time" male clients that I didn' I need to be paid for my work because, after all. all I was handling was their divoree and they were paying retainers to my malc colleagues for far more important work. My partners couldn't handle the tension so they quit referring to me and switched to junior male colleagues.

- It is of course not always possible to know how often this happens as people may not always be honest re their choice of counsel and some files may pass over a person without them knowing they were even considered or regarded.

-... I did experience a situation where one client told me thall a woman s place was in the home, but then apologized to me once he realized that he had made the comment to me.

- In matrimonial law, the clients often choose lawyers by gender. Often a female client will prefer a male lawyer because she thinks she will get a tough/aggressive lawyer which in my experience is completely erroneous. 
-...I have also been told that "our clients prefer men." Did they take a survey? I have only once had a client question my sex. He was concerned I might be biased in favour of his wife. I represent many males and females and do not find this a problem.

- On two occasions in the last five years I was advised that the client didn't want to work with me because I'm a woman. On one occasion this occurred after my senior partner had chosen me for the file because I had more experience in that area than any of the other litigation lawyers in my firm.

For me the issues here are:

I. what attempts do the other members of the firm make to promote acceptance by clients of femalc lawyers, and

2. is the fact that some clients prefer not to work with women going to affect the value of female lawyers to the law firm?

One of the lawyers in my department organized a luncheon to promote a new client with whom he had a number of contacts. Lunch was at the Petroleum Club, and I was not invited to attend, although men much my junior were. It was described to me as an "oversight", although I understand that a number of the lawyers invited thought it was pretty bad form. For me, it was more frustrating to be left out by a colleague than to have an unknown client judge me on the basis of his own prejudices.

- [Our firm policy is] not to allow clients to ask not to work with a specific gender or the client won't be represented.

Two men commented that they had had a female client who preferred a female lawyer. Other comments by men included:

- I have had a number of male clients in divorce situations ask me to refer them to a female lawyer to deal with their matrimonial problems, and had some females ask for the same thing. I have never had the same request in regard to specifically asking for a male. I refer out almost $99 \%$ of my matrimonial work.

- Many people prefer female divore lawyers in order to be able to handle female lawyers in opposition.

- Some criminal clients preler a female lawyer. It probably happens 3-4 times, mostly wilh female clients (out of 300 clients in the last 2 years).

In the last five years, $36.5 \%$ of the women, but only $5.1 \%$ of the men, were denied an opportunity to work on a file because another lawyer in their firm preferred a lawyer of the opposite gender. ${ }^{81}$ This experience happened "often" or "sometimes" to $24.8 \%$ of the women and $1.6 \%$ of the men. One woman commented that it was "difficult to break into the "boys club' to establish new clients," while other women wrote:

- A lawyer in the firm required a junior associate in the corporate area. He specifically stated to me. and several others in the firm. that he did not want a woman because they always get pregnant and leave.

xI. In the British Columbia survey. $10.1 \%$ of the women and $1.0 \%$ of the men reported being denied an opportunity to work on a file becituse a lawyer objected to them doing so on the basis of gender, ibid. at 112. 
- I have had to give a file to another lawyer in the office because the lawyer on the other side could not or would not deal with a woman - such circumstances make it costly and difficult to serve one's client's best interests.

- I was pregnant last year and found that most work requiring even peripheral client contact was given to other associates. In general, I was given much less work during the visible portion of my pregnancy and was later criticized for low billing during that time.

- It was suggested to me by a lawyer practising in the corporate commercial field that some clients had a difficulty with women lawyers.

A man commented:

- Occasionally a lawyer of either sex will harbour a discrimination to the opposite. 1 suppose that is just human nature but I would like to point out that it flows both ways.

\section{F. PERSONAL EXPERIENCE WITH DISCRIMINATION}

Question 40 asked respondents whether they had experienced discrimination while seeking employment as a lawyer or while employed as a lawyer on the basis of sex, colour or race, disability, age, marital status, sexual orientation, parental status, or an "other" category. Question 59 asked respondents who had articled between 1980-1991 whether they had experienced any problems finding articles on the basis of the same factors.

\section{Discrimination on the Basis of Sex ${ }^{\mathrm{x} 2}$}

Over one-half of the women $(58.7 \%)$ had experienced discrimination by lawyers on the basis of sex, and $38.7 \%$ had experienced discrimination by clients on the basis of sex. Only $3.3 \%$ of the men reported discrimination by lawyers, and $3.7 \%$ reported discrimination by clients.

Two women and three men commented that some women prefer a female lawyer in the matrimonial area. One of the men added, "perhaps understandably." Another woman wrote:

- While articling. I was doing an intake interview with clients who, after l'd finished getting information. asked when they would get to see the "real" lawyer. These clients had thought I was a secretary because I was femalc. I have also had clients express surprise that I was a lawyer, because they didn't know there were any women lawyers; however, they were quite happy to stay with me.

One woman said she was paid $2 / 3$ of what male lawyers with less experience were paid, and another made a similar comment with regard to the discrepancy in salaries and 
positions between women and men. One wrote that the discrimination was by judges. Other women wrote:

-...The most common problem I have encountered is a lack of respect from other counsel. Many of my colleagues, particularly in the family law bar, did not take me seriously. While this meant that I was generally more prepared (and therefore often more successful in) contested matters, it hampered negotiations and unnecessarily lengthened proceedings. As well, it became very wearing. and was one of the reasons I left private practice.

- My experience with gender bias has not been as apparent as when I first arrived in Alberta five years ago. I am generally perceived, on first contact, as younger than I am and have, from time to time, been treated as "little girl lawyer"! The condescending attitude of some middle-aged lawyers causes me to take a harder-line view than otherwise. There is a remark, "you're fondling this case." I do not have problems with lawyers in this firm. I fecl my opinion is sought out and respected on issues of law and the way the office is run. I encounter from time to time lawyers outside the firm. who either because of their clients or their own attitudes feel a need to "beat down the broad" - that sort of mentality. It can be very frustrating and I see people using any means necessary to do so. I once had a file I inherited from another lawyer in the firm, who noticed I was being treated without any of the usual courtesies and he concluded that the other lawyer had a "woman" problem.

- I graduated in the top $1 / 4$ of my class, and had first pick of articling positions. By the end of my year of articles, there was a recession and the firm decided that it could keep only $[1 / 2$ of the students $\mid . .$. The women were let go. This firm had other women associaltes and one woman partner. In my opinion. however, when the firm had to choose between competing candidates the following factors miligated against the women being selected: a. many partners had never assigned work to me, therefore their vote went to a man; b. perception that because I had a husband to support me. I needed the position less than the man; c. perception that because I had children I was less committed to my career (even though this had never interfered with my work): d. general discomfort with assertive women. In short, when push comes to shove. the women get pushed.

I was unable to obtain any other salaried position, and eventually started my own practice with a group of lawyers. With no client base to start with. and high overhead. it has taken a number of years to turn a profit.

I find it difficult to believe that a man with my academic standing, and pleasant personality, would have ended up in this position.

- I have been asked how I would deal with suppon staff (not one of my male colleagues has ever been asked this). . . I am sick of being asked for my Bar Card and having every corner of my briefcase searched while I watch males go by without either. I have seen other females searched in similar fashion. I resent being placed in interview rooms near the front so they can "watch for passing of contraband." Just because I'm a woman doesn't mean I'll do anything for male prisoners.

- Yes, it is one sided. When I was first admitted I didn't feel this way. But after lover 5] years of observation and experience $I$ am mad!

- It is disgusting to watch a judge give 3 months probation for a male altacking his boss in the washroom and say in mitigation. 1. he only fondled her breasts. 2: his young male hormones. Where is there an 
equivalent defence for females. Years of abuse and battery and a recognized syndrome is all too often rejected as even being a factor. And I wonder how he'd react to my forceable fondling of his penis?

Four men commented on how affirmative action affected their job prospects, and another wrote, "my christian name has a "female" quality and I experienced discrimination prior to meeting face-to-face."

While looking for articles, $33.0 \%$ of the women and $1.3 \%$ of the men experienced problems finding articles on the basis of sex. Experiences described by women included being asked whether she could type (in 1981), the expectation in two firms that women do family law, being told during the articling interview that while the firm was interviewing women a decision "had been made that none would be hired." Other comments by women included:

- No, not in 84, but I did in 1979 when I first tried. My impression is that the situation improved in the 5 years between my first and second attempt to secure articles. If there was discrimination, it was more subtle.

- While I did not have problems obtaining an article, one of the interviewers at the firm at which I did not accept a position referred to the lawyers in the firm as "lawyers and girl lawyers." "Lawyers" without qualification clearly referred to "natural lawyers" i.e. men.

- A senior partner al a medium-sized firm commented, "I can’t imagine my wife wanting to be a lawyer."

- After a second interview I was advised that, in the event I was not offered a position it would be because my marks were not high enough. I was al the time aware of the firm already having hired a male for one of their articling positions whose GPA was exactly the same as mine.

- I did not have much difficulty finding articles, but I did want to inform you of the articling interview I had with flaw firm]. The interview itself was so unpleasant I left with a headache and fecling sick. I remember telephoning . . . and telling them this was one job I was not going to get. I was telephoned by one of the persons who had interviewed me and he really said to me "quite frankly you'll agree with me that you are not much of a cheer-leader" and that therefore they did not wish to hire me. 1 agreed with this person that I was not much of a cheer-leader, but I have often wondered why this large law firm would possibly think that I should be a cheer-leader and even what this comment meant.

That interview was one of the reasons I did not want to interview for jobs and went into sole practice.

\section{Discrimination on the Basis of Being a Visible Minority}

Six of the 18 women $(33.3 \%)$ who identified themselves as members of visible minorities experienced discrimination by lawyers on the basis of colour or race, five (27.8\%) experienced discrimination by clients. Twenty-six of the 76 men (34.2\%) who identified themselves as a member of a visible minority experienced discrimination by lawyers on the basis of colour or race, $22(28.9 \%)$ experienced discrimination by clients. One woman who was a member of a visible minority indicated that she was not discriminated against and then added, "But I was a top student." One woman commented: 
-...Both men and women in visible minorities or with disabilities face discrimination; I have no reason to believe that women in these categories are treated any better, relative to men in these groups, than they are in the white able-bodied population of lawyers. While I can think of many situations where female lawyers (and even judges) have been discounted, criticized on irrelevant grounds, put down, humilialed and embarrassed because they are women. I have not been able to recall a single similar incident based on the "male-ness" of a male lawyer or judge.

A man wrote:

- I am male and a "WASP." Since lindicating I have never been discriminated against| I have been discharged by a black client who preferred a fellow hlack as a lawyer.

One woman was discriminated against by employers who assumed she was the race which her married last name indicated, and another was hired, in part, because of her "connections/network" associated with race and religion. Three men reported discrimination by clients and lawyers on the basis of ethnic origins or nationality and two men reported such discrimination only by lawyers.

Three women and 19 men experienced problems finding articles on the basis of colour or race.

\section{Discrimination on the Basis of Disability}

Six of the 26 men and none of the six women who considered themselves disadvantaged by reason of a persistent disability reported discrimination on the basis of disability. Ten other men and one other woman reported discrimination on the basis of disability.

Five men with disabilities experienced problems finding articles. One respondent wrote:

- During the article interviewing process it was never stated by prospective employers that my disability (quadriplegia) would be a hinderance to employment but it seemed evident that concerns existed as to whether the job could be performed to the standard expected of an able-bodied individual. The concern seemed to stem more from this fact rather than from the notion that it would be detrimental to hire a disabled person because of their disability per se.

\section{Discrimination on the Basis of Age}

Discrimination by lawyers on the basis of age was reported by $19.5 \%$ of the women respondents and $8.2 \%$ of the men. Discrimination by clients was experienced by $14.5 \%$ of the women and $8.0 \%$ of the men respondents. There was some indication from the comments that discrimination on the basis of age may be because one is "too old" or "too young." One woman said she was discriminated against because she looked too young, and another wrote: 
- There is the perception, held both by other lawyers and clients, that 1, a middle-aged, married woman, am "lawyering" merely as a hobby or side line to augment the household income or to nurture/amuse my intellectual self.

The reality is that I strive for excellence in the practise of law with the same personal commitment and financial responsibility (read this as capital/operating loans!) as any male endeavouring to establish a successful business.

Two men reported discrimination in seeking employment because they were "too old," three reported clients wanted older more experienced lawyers, and three reported that their youth was a factor (one was denied earlier promotion because of age).

Two women were of the view that there was more discrimination on the basis of age than there was discrimination on the basis of sex. One wrote:

- Discrimination on the basis of age is much more insidious than that of sex. The latter can at least be perceived and addressed. It is sad, because life experience adds skills and qualities beyond formal education and training, and cannot be measured in grades. I wonder whether "older" men face this discrimination. The age factor is the next area to be studied (I hope). When I entered law school in my 40 's it never occurred to me that gaining admission would be easier than getting a position afterwards!!!

Sixty women (13.9\% of those who articled between 1980-1991) and 73 men (8.5\%) experienced problems finding articles because of age. Two women and two men stated they had problems because they were too young, and two women stated that they had problems because they were too old.

\section{Discrimination on the Basis of Marital Status}

Discrimination by lawyers on the basis of marital status was experienced by $13.5 \%$ of the women and $2.4 \%$ of the men. Such discrimination by clients was reported by $3.5 \%$ of the women and .7\% of the men. One woman and one man said they were discriminated against in hiring because they were not married. The man was told that this was the sole reason he was not hired. One woman wrote:

- I believe that the decisions reached regarding my remuneration were coloured by the fact that I had a spouse that also had a professional income. Therefore, I did not need to be paid as much as someone in an equivalent position that was married to a spouse that stayed at home or single person.

Forty-four women and 30 men reported having problems finding articles because of marital status. Two men reported having problems because they were single. One man wrote:

- Two articling interviews stick in my mind. Both were conducted by female lawyers. One told me outright that her firm (a largish Calgary one) tended to keep on married students, as they were harder and more reliable workers. There was a large hint there that I would have to marry my common law at least by the end of articles!

In the other the interviewer asked me such personal questions that I almost got up and left the intervicw. As it happened my answers were truthfully ones I realized she wanted to hear. Such as: I was living in 
a common law relationship, and would probably get married when we decided to have kids. And yes my common law tends to complain that I spent too much time on studies, and that habit would carry over into the work place, and did I realize that I would be expected to put workplace time before children time. At the end of the interview I asked that my name be withdrawn from consideration at that firm. I got the impression that this firm did not want anyone interested in a family life.

\section{Discrimination on the Basis of Parental Status}

Discrimination by lawyers on the basis of parental status was experienced by $14.0 \%$ of the women and $1.6 \%$ of the men. Such discrimination by clients was reported by $.8 \%$ of the women and $.4 \%$ of the men. Comments by women included:

- I have been told to get married and raise children before trying to practise. I am routinely questioned about my marital status and plans...

- I believe I was not hired by some firms because of my intention some day to have a family (which I have done).

-... [when] I was a divorced single parent. I was roulinely subjected to questioning during interviews which indicated that many firms were sceptical as to my ability to manage a job despite my excellent law school performance (I was a single parent then also) as I finished in the top 20 in my class.

- I ... believe that I became expendable to my firm when I became a parent.

- The common perception is that women lawyers jump off the fast track and onto the slow track once they have a family. The truth is that many women lawyers end up on the slow track before they ever have a family.

-... As a parent, I have commitments to meet (driving the kids to school, day care that ends at 6:00, dental appointments, etc. etc.). My partners love to set breakfast meetings or evening/weekend meetings on the assumption that 1 also have a "wife" who will pick up the kids - I don'l: I have a husband who shares the load but has commitments of his own.

- While seeking articles I was questioned about what I would do if I became pregnant and if I objected to abortion.

- Fear I might get pregnant (by other lawyers) llead to being] asked numerous questions at interviews about my intention to have a lamily.

Two other women experienced discrimination by lawyers while they were pregnant.

Thirty-four women and 18 men had problems with respect to parental status when it came to looking for articles. Seven women stated that they were asked questions regarding their intentions to have children during articling interviews and their ability to cope with work and family. Six additional women had problems because they had children or were pregnant at the time. Comments included: 
- I experienced difficulty because I was not prepared to accept articles where I felt that consideration would not be given to my parental status. For the most part I did not even apply to large fïrms where I understood the problem was acute.

- I found when looking for articles that the law firms hired men with the same marks before they would hire me or the other women in the class. When I was interviewed by the various lawyers in the law firms some of them asked questions that I could not believe they were asking. For example, they would ask if I planned to get pregnant, that they only had one bathroom and what would 1 do, did I plan to get married and other personal things. I felt that there was a strong bias against women.

I was also younger than most people in law school at the time and felt that I was not considered seriously because of this. I must add however that interviewing is a skill that can be learned and obviously taught. I had never learned the skill at that time and that was certainly a handicap. If there is a practical course that could be taught in law schools interviewing is one.

- In 1985. 1 firm denied me an articling interview because I had a child (I am a mother) and they felt this slowed an obvious lack of commitment to the profession (I went on to have a second child and I'm still praclising).

- In terms of linding employment as an articling student, although I faced some foolish questions of a sexist nature. I did not have any difficulty securing a position. Questions asked included when I was planning to start my family and an inordinate amount of time spent in discussing my spouse's job plans. In my second employment search I had no problems based on either sex or parental status.

- In the majority of the articling interviews the questions focused on: my marital status, my husband's employment, whether I would move if he was transferred, if I planned on having any more children, was I seriously interested in being a lawyer since I was married and had children, etc. For example, in a halfhour interview, 5 minutes or less focused on my abilities, interests, academic standing and 25 minutes on my husband's employment/economic situation.

I accepted an articling position at one of the 3 firms that did not demonstrate this prejudiced attitude loward women.

- I felt a distinct disadvantage in trying to explain throughout law school that 1 parented full time and worked part time as well as attending law school. I did not want to appear to be a whiner, begging for sympathy, and yet I feel these facts are significant in explaining why I didn't maintain a higher grade point average. As well, the fact that I was not able to participate as fully in the cxtra curricular activities seemed to weigh in decisions, but no one was particularly interested in why.

\section{Discrimination on the Basis of Sexual Orientation}

Respondents were not asked their sexual orientation; however, three women and eleven men experienced discrimination by lawyers on the basis of their sexual orientation, and two women and seven men experienced such discrimination by clients.

\section{CONCLUDING COMMENTS}

This study is part of a growing body of national and international literature which has concluded that gender bias exists in the legal profession. A majority of the respondents 
in this survey of active members of the Law Society of Alberta $(97.2 \%$ of the women and $77.6 \%$ of the men) thought that there was some form of gender bias against women in the legal profession in Alberta.

There were a number of concerns which emerged from this study which are similar to those raised in other studies across Canada. So far, two committees have considered the results of surveys similar to this one and made recommendations regarding some of the issues women face in the legal profession. ${ }^{83}$ These reports may be useful starting points for the Joint Committee and other committees in addressing the question of what should be done about gender bias in the legal profession. In addition, discrimination on the basis of race, disability, age and sexual orientation are also issues of concern.

\section{A. THE GLASS CEILING AND THE GLASS BOX}

John Hagan has suggested that women lawyers may not have access to the same mobility ladders as men do. ${ }^{x-4}$ This might be considered an aspect of what is sometimes referred to as the "glass ceiling." ${ }^{* 5}$ Career advancement and attaining partnership were the most frequently mentioned forms of bias against women identified by both women and men. Over one-half of the women had experienced discrimination by lawyers on the basis of sex and $38.7 \%$ had experienced discrimination by clients on the basis of sex. One third of the women who articled between 1980 and 1991 had experienced discrimination on the basis of sex during their search for articling positions.

The Subcommittee on Women in the Legal Profession in British Columbia has recommended that the Law Society create a position for an Equal Opportunities Coordinator and that:

Recommendation 16: The Law Society direct the Equal Opportunities Co-ordinator to prepare model policies for firms and other legal employers on guidelines for interviewing prospective articling students and associates and assist and advise firms and other legal employers in instituting such policies.

Recommendation 17: The Law Society establish an educational resource for all members on the issue of gender bias in the profession.

Recommendation 18: The Law Society advise its members of:

a) the obligations law firms have to refrain from discriminating on the basis of sex:

b) that discrimination against women within the profession infringes the Human Rights Code.

Recommendation 19: The Professional Conduct Handbook be amended to state clearly that discrimination on the basis of sex in employment is professional misconduct.

x?. Sec Kay, supra, note 4 at 107 and Young ef al.. supra, note 5.

x. Hagan, supra, note 16 at 8.36 .

xs. Sec for example, A. M. Morrison et al., Brcaking the Glass Ceiling: Cam Women Reach the Top of America's Largest Corporatioms?' (Mass: Addison-Wesley. 1987). 
Recommendation 20: The Law Society take a leading role in eliminating discrimination against women in hiring and promotional policies and make efforts to eradicate discrimination in the profession. ${ }^{{ }^{\star 6}}$

The Law Society of Upper Canada's Committee on Women in the Legal Profession recommended that the Law Society ask its Professional Conduct Committee to determine "whether there are specific aspects of discrimination that may require further attention in the Rules of Professional Conduct" and to disseminate within the profession information and policies regarding sexual discrimination and other forms of discrimination under human rights legislation. ${ }^{87}$

Faced with discrimination, some women in this survey left law firms to start their own practice. A recent study by the Advisory Council on the Status of Women has suggested that:

women who look to self-employment as an alternative to the glass ceiling may in fact be trading a glass ceiling for a glass box - a unique form of isolation that prevents them from reaching out to seize the opportunities that surround them. ${ }^{\mathrm{xx}}$

The authors identify eight obstacles which prevent women from breaking out of the glass box and make a number of suggestions for networking and getting advice which may have some application for both women and men in the legal profession. ${ }^{89}$

\section{B. LACK OF ACCOMMODATION FOR FAMILY COMMITMENTS}

According to some of the respondents in this survey, the legal profession is not very accommodating for either women or men who have children. However, the consequences of this lack of accommodation usually fall more heavily on women. Sixty-five percent of the women and $22.3 \%$ of the men were of the view that lack of accommodation for family commitments was an area in which women were discriminated against in the legal profession, and $15.0 \%$ of the women and $11.1 \%$ of the men were of the view that this was an area in which men faced discrimination. A number of women in this survey associated the termination of their employment with the birth of their children.

Parental leave is not an issue which is easily resolved in a profession with a large number of self-employed people, where over half of the lawyers work in firms or organizations with fewer than ten lawyers. A number of respondents expressed concern that this questionnaire was designed for large, urban firms. Solutions to some of these issues need to be sensitive to the diversity of the legal profession.

There is also a need for more flexibility in the legal profession to accommodate or provide part time work. In this survey $9.3 \%$ of the women and $1.3 \%$ of the men worked part time and were not seeking full time work. Part time work was an available option

\footnotetext{
th. Young et al., stupra, note 5 at 30-31.

x7. Kay, supra, note 4 at 113.

*x. Belcourt, et al., supra, note 23 at 1.

x. Ibid. $70-75$.
} 
where $36.5 \%$ of the women and $30.6 \%$ of the men worked; job sharing was available where $16.1 \%$ of the women and $18.2 \%$ of the men worked. However, there were a number of women who had difficulty switching to part time work after the birth of their children. Some women had to resign their partnership status because they were not allowed to be part time partners. Only $6.3 \%$ of the women and $5.3 \%$ of the men reported the availability of part time partnership.

The Law Society of British Columbia's Subcommittee on Women in the Legal Profession has recommended that the Law Society "promote alternative types of practice, including part-time, flexible time and job sharing," and that it encourage these possibilities through "lower fees and lower insurance premiums for Members working part-time." Its recommendation included:

Recommendation 3: The Law Society appoint an Equal Opportunities Co-ordinator to prepare model policics for firms and other employers:

(a) on part-time work, job sharing. flexible work hours and locums; and

(b) to assist and advise firms and other legal employers in instituting such policies.

Recommendation 4: Law firms should be encouraged by the Law Society to expressly recognize the competing claims of career and family obligations and establish reasonable billing requirements for fulltime associates and partners.

Recommendation 5: The Law Society encourage law firms to develop maternity leave policies for women associates and partners and be model employers in this regard."

The Subcommittee also recommended that the Law Society direct the Equal Opportunities Co-ordinator to "draft standard maternity leave policies for law firms setting out compensation," etc., and that the Law Society "encourage firms to consider instituting career break schemes." ${ }^{.92}$ Similar lifestyle and alternative career options were recommended by the Ontario Committee. ${ }^{93}$

\section{SEXUAL HARASSMENT}

Sexual harassment exists in the legal profession in Alberta, as it does in other provinces. This survey did not canvas the effects of sexual harassment on women, and it was clear from some of the comments that some lawyers do not understand these effects. Sexual harassment is not a sexual encounter for its victims and is somewhat of a misnomer. Studies of sexual harassment have established some of the damaging effects that it has on women. In one study, nervousness, irritability and uncontrolled anger were

Ihid. at 13-16.

92. Ihid. at 17-19.

4.1. Kay, supra, note 4 at 109-112. See also: Oregon Women Lawyers Group, The Parent Track and the Partner Track: It Can Be Done and The American Bar Association Commission on Women in the Profession, Lawyers and Balanced Lives: A Guide to Drafting and Implementing Workplace Polices for Lawyers (Chicago: American Bar Association). 
the most frequently cited responses. ${ }^{94}$ In another study, the author found that disgust (2/5th of women respondents) and anger (1/3 of women respondents) were the most common reactions to sexual harassment. ${ }^{95}$ One researcher found that $12 \%$ of her respondents sought psychological help as a result of their experience. ${ }^{96}$

In arriving at the conclusion that sexual harassment was discrimination on the basis of sex in the Janzen case, Chief Justice Dickson (as he then was) concluded:

\begin{abstract}
sexual harassment... is unwelcome conduct of a sexual nature that detrimentally affects the work environment or leads to adverse job-related consequences for the victims of the harassment... [It| is a demeaning practice. one that constitules a profound affront to the dignity of the employees forced to endure it... [II] attacks the dignity and self-respect of the victin both as an employee and as a human being."
\end{abstract}

Sexual harassment is a violation of human rights. The Law Society of British Columbia's Subcommittee on Women in the Legal Profession has suggested that sexual harassment be included in the definition of professional misconduct, and that an Equal Opportunities Co-ordinator receive complaints regarding sexual harassment and mediate or refer such complaints to the Discipline Committee. ${ }^{\%}$ Lawyers presently advising executives and in-house counsel about the merits of sexual harassment policies ${ }^{99}$ may have to follow their own advice.

The Law Society of Upper Canada has recently circulated a Recommended Personnel Policy Regarding Employment-Related Sexual Harassment to managing partners in law firms throughout Ontario. Government departments and universities have developed policies and educational programmes on sexual harassment. More recently, organizations have turned to harassment polices which cover abusive behaviour, whether based on sex or other characteristics of individuals. This approach is now considered a more advanced approach than the narrower "sexual" harassment approach. ${ }^{100}$

\title{
D. OTHER FORMS OF DISCRIMINATION
}

Only $3.0 \%$ of the women and $4.2 \%$ of the men in this survey were members of visible minorities. Approximately one-third of these women and men had experienced discrimination by other lawyers on the basis of colour or race while seeking employment as a lawyer or during the course of their employment as a lawyer. Six women and 26

P. Hewitt Loy and L.P. Stewart, "The Extent and Effects of the Sexual Harassment of Working Women" (1984) 17 Sociological Focus 31 at 37.

w5. B.A. Gutek, Sex and the Workplace (San Francisco: Jossey-Bass Publishers, 1985) at 71.

พ. P. Crull, "The impact of sexual harassment on the job: A profile of the experience of 92 women" (1979) Working Women's Institute Research Series Report no. 3 cited in Loy and Stewart at 33. Janzen and Govereau v. Platy Enterprises L.d. et al., [1989] 4 W.W.R. 39 (S.C.C.) at 64-65.

"x. Young et al., supra, note 5 at 37.

w. Sec for example, D. Brillinger, "Sexual Harassment Measures are Crucial, Employers Told" Lawyers Weckly (10 January 1992) 8; and "Workplace Sexual Harassment Policy Will Head off Problems" Lawyers Weekly (10 January 1992) 9. 
men in this survey considered themselves disadvantaged by reason of a persistent disability. Six of these men and none of the women reported discrimination on the basis of disability. Ten other men and one other woman reported discrimination on the basis of disability.

Discrimination on the basis of age while seeking employment as a lawyer or during the course of their employment as a lawyer was experienced by $19.5 \%$ of the women and $8.2 \%$ of the men. Some of these experiences were because the respondent was "too old" and others because the respondent was "too young."

Three women and eleven men experienced discrimination on the basis of sexual orientation. This small number is probably due to the fact that gay and lesbian lawyers are, for the most part, not revealing their sexual orientation for fear of discrimination. The Gender Bias Committee of the Law Society of British Columbia recently heard from gay and lesbian lawyers in Vancouver, and their report might shed some light on what it is like to relate to the law "as fugitives, outsiders." ${ }^{101}$

The recent interest in studying women in the legal profession may provide the necessary catalyst to re-examine the role of lawyers in our society and "to ensure that the legal profession itself is responsive to goals of equality and justice accepted within Canadian society." ${ }^{102}$

161. A lawyer quoted at the B.C. Law Society Gender Bias Committee hearings, by the Vancouver Sun (25 January 1992) BI.

112. Supra, note 11. 


\section{TABLE 1}

\section{Proportion of Respondents Who Are Living in a Married or Equivalent Relationship, by Gender and Age'}

\section{AGE OF RESPONDENTS}

$\begin{array}{lllll}<30 & 30-34 & 35-39 & 40-44 & 45+\end{array}$

\section{Women Men Women Men Women Men Women Men Women Men}

$\begin{array}{lllllllllll}\text { NO. MARRIED } & 63 \% & 53 \% & 77 \% & 79 \% & 80 \% & 89 \% & 78 \% & 89 \% & 65 \% & 88 \%\end{array}$

$\begin{array}{lllllllllll}\text { TOTAL } & 99 & 155 & 186 & 352 & 169 & 513 & 92 & 351 & 37 & 390\end{array}$

Conditional

Gamma

Chi-Square
.20

.06

.32

$7.301^{* *}$
.40

.61 


\section{TABLE 2}

\section{Number of Children Respondents Have,} By Gender and Age Categories'

\section{AGE OF RESPONDENTS}

$<35$

35-39

$40+$

\section{NUMBER OF}

CHILDREN

Women Men Women Men Women Men

none

$56 \%$

$33 \%$

$21 \%$

$34 \%$

$16 \%$

one

$22 \%$

$14 \%$

$12 \%$

$14 \%$

$12 \%$

$8 \%$

two

or more

16

$30 \%$

$56 \%$

$65 \%$

$54 \%$

TOTAL

Conditional

Gamma 
TABLE 3

Perception of Gender Bias in the Legal Profession

\section{BIAS AGAINST WOMEN}

There is none

Exists, but is not

widespreasd

Widespread, but subtle and difficult to detect

Widespread and

readily apparent

No response

TOTAL.

\section{Women}

$7(1.2 \%)$

$152(25.3 \%)$

$331(55.2 \%)$

$100(16.7 \%)$

$10(1.7 \%)$

$600(100 \%)$

\section{Men}

$338(18.8 \%)$

$968(53.8 \%)$

$3.3(19.6 \%)$

$74(4.1 \%)$

$65(3.6 \%)$

$1798(100 \%)$

\section{BIAS AGAINST MEN}

There is none

Exists, but is not

widespread

Widespread, but subtle and difficult to detect

Widespread and readily apparent

No response

TOTAL
$1.34(22.3 \%)$

$672(37.4 \%)$

$1 \quad(.2 \%) \quad 43 \quad(2.4 \%)$

$2(.3 \%) \quad 36(2.0 \%)$

$7 \quad(1.2 \%) \quad 56 \quad(3.1 \%)$

$600(100 \%) \quad 1798(100 \%)$ 


\section{TABLE 4}

Nature of Bias in the Legal Profession'

$\begin{array}{lllll} & \text { Against } & \text { Against } & \text { Against } & \text { No Bias/ } \\ \text { NATURE OF BIAS } & \text { Women } & \text { Men } & \text { Both } & \text { No Response }\end{array}$

1) lawyers not giving appropriate

weight to opinions

$\begin{array}{lllll}\text { women } & 59.7 \% & 0 \% & .5 \% & 39.8 \% \\ \text { men } & 20.6 \% & .9 \% & 1.5 \% & 76.9 \%\end{array}$

2) career advancement

$\begin{array}{llrrr}\text { women } & 81.8 \% & .5 \% & .5 \% & 17.2 \% \\ \text { men } & 42.4 \% & 4.7 \% & 2.2 \% & 50.7 \%\end{array}$

3) access to clients

$\begin{array}{lllll}\text { women } & 57.5 \% & .3 \% & 1.3 \% & 40.8 \% \\ \text { men } & 25.3 \% & 1.2 \% & 2.6 \% & 71.0 \%\end{array}$

4) assignment of files/work women

men

5) setting hourly rates

$\begin{array}{lllll}\text { women } & 14.3 \% & .2 \% & .2 \% & 85.3 \% \\ \text { men } & 5.3 \% & .8 \% & .2 \% & 93.7 \%\end{array}$

6) remuneration

$\begin{array}{lllll}\text { women } & 51.0 \% & .3 \% & .2 \% & 48.5 \% \\ \text { men } & 14.2 \% & .4 \% & .3 \% & 85.1 \%\end{array}$

7) hiring

$\begin{array}{lllll}\text { women } & 54.2 \% & 1.0 \% & 1.2 \% & 4.7 \% \\ \text { men } & 24.2 \% & 4.3 \% & 2.1 \% & 69.4 \%\end{array}$

8) attaining partnership

$\begin{array}{lllll}\text { women } & 70.7 \% & .3 \% & 0 \% & 29.0 \% \\ \text { men } & 34.9 \% & .6 \% & .7 \% & 63.8 \%\end{array}$

9) access to managerial positions

$\begin{array}{lllll}\text { women } & 52.8 \% & .2 \% & .3 \% & 46.7 \% \\ \text { men } & 17.5 \% & 1.1 \% & .4 \% & 81.0 \%\end{array}$


Table 4 cont.

\section{NATURE OF BIAS}

Against

Women

10) opportunity to appear in court
women
$15.7 \%$
men
$4.1 \%$

11) judicial attitudes
women
men
12) unwanted sexual advances

$54.5 \%$

$21.7 \%$

women
men

$37.0 \%$

$17.2 \%$

13) unwanted teasing, jokes

women $\quad 57.7 \%$

men

$25.3 \%$

14) nature of office/firm functions

$\begin{array}{ll}\text { women } & 40.5 \% \\ \text { men } & 9.5 \%\end{array}$

15) nature of promotional functions

$\begin{array}{ll}\text { women } & 41.8 \% \\ \text { men } & 9.8 \%\end{array}$

16) judicial appointments

$\begin{array}{lllll}\text { women } & 16.5 \% & 11.3 \% & .8 \% & 71.3 \% \\ \text { men } & 3.1 \% & 26.3 \% & .4 \% & 70.2 \%\end{array}$

17) lack of accommodation

for family commitments

$\begin{array}{lllll}\text { women } & 50.8 \% & 1.2 \% & 13.8 \% & 34.2 \% \\ \text { men } & 16.1 \% & 4.9 \% & 6.2 \% & 72.7 \%\end{array}$

$\begin{array}{lll}\text { Against } & \text { Against } & \text { No Bias/ } \\ \text { Men } & \text { Both } & \text { No Response }\end{array}$

$\begin{array}{lll}0 \% & .5 \% & 83.8 \% \\ .6 \% & .1 \% & 95.2 \%\end{array}$

$.5 \%$

$.8 \%$

$44.2 \%$

$3.8 \%$

$1.9 \%$

$72.6 \%$

$\begin{array}{lll}.2 \% & 1.8 \% & 61.0 \% \\ .7 \% & 1.3 \% & 80.8 \%\end{array}$

$.3 \%$

$3.5 \%$

$38.5 \%$

$70.9 \%$

$58.2 \%$

$89.7 \%$

$.2 \% \quad 89.7 \%$

$\begin{array}{lll}.2 \% & .2 \% & 57.8 \% \\ .6 \% & .1 \% & 89.5 \%\end{array}$

$89.5 \%$

$70.2 \%$

$72.7 \%$

The percentages of women and men who identified each type of bias are of the 600 women and 1798 men who responded to the survey.

$2 \quad$ "No response" includes all those who did not indicate a form of bias against women or men. Some of these respondents may simply have chosen not to answer the question; therefore, the perception of gender bias could be more widespread than would appear from this Table. 


\section{Table 5}

Percentage of Respondents in Private Practice

Who are Partners, by Gender and Year of Call

Women

$$
6 / 11 \quad(54.5 \%)
$$

$36 / 60(60.0 \%)$

$49 / 139(35.3 \%)$

$16 / 191(8.4 \%)$
Men

280/424 (66.0\%)

219/333 (65.8\%)

199/357 (55.7\%)

$31 / 337$ (9.2\%)

1986-1990 


\section{TABLE 6}

\section{Mean and Median Income of Respondents Who Work Full Time, by Year of Call}

\begin{tabular}{|c|c|c|c|c|c|c|}
\hline \multirow[t]{2}{*}{$\begin{array}{l}\text { YEAR OF } \\
\text { CALL }\end{array}$} & \multicolumn{2}{|c|}{$\begin{array}{l}\text { NUMBER OF } \\
\text { RESPONDENTS }\end{array}$} & \multicolumn{2}{|c|}{ MEAN } & \multicolumn{2}{|c|}{ MEDIAN } \\
\hline & Women & Men & Women & Men & Women & Men \\
\hline 1990 & 65 & 70) & 36.938 & 33,186 & $34,(000$ & 33,000 \\
\hline 1989 & 37 & 66 & 37,730 & 42,394 & 40,000 & 40,500 \\
\hline 1988 & 39 & 85 & 47,103 & 51.718 & 45.000 & 50,000 \\
\hline 1987 & 41 & 79 & 54,610 & 56,924 & 52,000 & 60,000 \\
\hline 1986 & 44 & 72 & 55,205 & 62,250 & 56.500 & 60,000 \\
\hline 1985 & 42 & 65 & 61,190 & 71,462 & 56.500 & 60,000 \\
\hline 1984 & 33 & 89 & 69.879 & 77.921 & $60.0(0)$ & 75,000 \\
\hline 1983 & 27 & 82 & 69.333 & 88,073 & $58.000)$ & 75,000 \\
\hline 1982 & 29 & 97 & 74,345 & 87,948 & 74.000 & 78,000 \\
\hline 1981 & 27 & 82 & 79.667 & 103,000 & 78.0000 & 92,500 \\
\hline 1980 & 31 & 98 & 89,419 & 107,612 & 75,000 & 90,000 \\
\hline $1975-79$ & 65 & 355 & 94,708 & 109,544 & 85,000 & 99,000 \\
\hline beforc & & & & & & \\
\hline 1975 & 14 & 384 & 78,071 & 128.846 & 70,500 & 102,000 \\
\hline Overall' & 494 & 1625 & 63.518 & 94,314 & 55.500 & 77.000 \\
\hline
\end{tabular}

I. Mean and median income of respondents, disregarding years of call. One man did not indicate his year of call; therefore, the overall number of male respondents is greater than the total number of male respondents by year of call. 


\section{TABLE 7}

\section{Percentage of Respondents Who Experienced Listed Consequences as a Result of Having Children since $1985^{\prime}$}

\section{EXPERIENCES}

1) loss of seniority

$.6 \%$

2) delay in promotion

$23.8 \%$

$1.0 \%$

3) loss of office space

$5.9 \%$

4) pressure to return to work during parental leave

$41.1 \%$

$1.9 \%$

5 pressure to work while on parental leave

6) unreasonable work load following parental leave

7) testing of commitment to work

8) loss of clients

9) loss of job

$10.3 \%$

10) difficulty in obtaining leave

$10.8 \%$

11) difficulty in obtaining flexible hours or part time work

12) loss of income

13) stress from

14) other

$3.8 \%$ $1.0 \%$ 
TABLE 8

\section{Benefits For Lawyers Available From Firm or Employer'}

\section{TYPE OF BENEFIT}

1) disability insurance

women $(\mathrm{N}=534)$

men $(\mathrm{N}=1577)$

2) leave of absence/sabbatical

women $(\mathrm{N}=489) \quad 51.3 \%$

men $(\mathrm{N}=1404)$

$45.4 \%$

$36.5 \%$

$30.6 \%$

men $(N=1413)$

$75.8 \%$

$70.8 \%$

3) part time work

women $(\mathrm{N}=523)$
YES

No

DON'T

KNOW

$21.7 \%$

$27.1 \%$

$2.4 \%$

$2.0 \%$

$100 \%$

$100 \%$

$27.8 \%$

$39.8 \%$

$20.9 \%$

$100 \%$

$14.7 \%$

$100 \%$

4) flexible work hours (full time work)

women $\mathrm{N}=522$ ) $\quad 52.1 \%$

men (1492)

$58.0 \%$

5) job sharing

women $(\mathrm{N}=490)$

$16.1 \%$

men $(\mathrm{N}=1369)$

$18.2 \%$

$6.3 \%$

$5.3 \%$

men $(\mathrm{N}=1153)$

$1.7 \%$

$2.1 \%$

men $(\mathrm{N}=1328)$

8) unpaid malemity leave (partners)

women ( $\mathrm{N}=346)$

$48.3 \%$

men $(\mathrm{N}=1023)$

$37.9 \%$

$61.9 \%$

$46.2 \%$
$50.9 \%$

$12.6 \%$

$100 \%$

$60.7 \%$

$8.6 \%$

$100 \%$

$39.3 \%$

$35.3 \%$

$8.6 \%$

$100 \%$

$6.6 \%$

$100 \%$

$67.1 \%$

$68.2 \%$

$16.7 \%$

$100 \%$

$13.6 \%$

$100 \%$
9) unpaid maternity leave

(associates/employees)

women ( $\mathrm{N}=433$ )

$90.4 \%$

$7.9 \%$

$100 \%$

$87.5 \%$

$10.4 \%$

$100 \%$

men $(\mathrm{N}=1176)$

$13.9 \%$

$24.2 \%$

$100 \%$

$25.0 \%$

$28.8 \%$

$100 \%$

$100 \%$

$32.3 \% \quad 100 \%$


Table 8 cont.

TYPE OF BENEFIT

10) unpaid maternity leave

(contract lawyers)

women $(\mathrm{N}=269)$

men $(\mathrm{N}=792)$

11) unpaid maternity leave (contract lawyers)

women $(\mathrm{N}=269)$

men $(\mathrm{N}=792)$

12) unpaid patemity leave

(partners)

women $(\mathrm{N}=348)$

men $(\mathrm{N}=1134)$

13) unpaid patemity leave

(associates/employees)

women $(\mathrm{N}=408)$

men $(N=1204)$

14) unpaid paternity leave

(contract lawyers)

women $(\mathrm{N}=287)$

men $(\mathrm{N}=918)$

15) paid maternity leave

(partners)

women ( $N=376$ )

men $(\mathrm{N}=1106)$

16) paid maternity leave

(associates/employees)

women $(\mathrm{N}=459)$

men $(\mathrm{N}=1233)$

17) paid maternity leave

(contract lawyers)

women $(\mathrm{N}=298)$

men $(\mathrm{N}=864)$
$5.9 \%$

$32.2 \%$

$32.9 \%$

$45.9 \%$

$22.0 \%$

$100 \%$

$8.4 \%$

NO

$25.3 \%$

$49.4 \%$

$100 \%$

$37.5 \%$

$44.2 \%$

$100 \%$

$25.3 \%$

$49.4 \%$

$100 \%$

$44.2 \%$

$100 \%$

$9.2 \%$

$40.5 \%$

$50.3 \%$

$100 \%$

$34.7 \%$

$100 \%$

$13.7 \%$

$38.5 \%$

$47.8 \%$

$100 \%$

$55.5 \%$

$34.9 \%$

$100 \%$

$29.5 \%$

$45.1 \%$

$25.4 \%$

$100 \%$

$8.8 \%$

$49.0 \%$

$42.6 \%$

$100 \%$

$52.2 \%$
$100 \%$

$100 \%$

$100 \%$

$100 \%$

$\begin{array}{ll}31.4 \% & 100 \%\end{array}$


Table 8 cont.

\section{TYPE OF BENEFIT}

18) paid paternity leave

(partners)

women ( $\mathrm{N}=370$ )

$\operatorname{men}(\mathrm{N}=1174)$

19) paid pattemity leave

(atsociales/employees)

women $(\mathrm{N}=426)$

men $(\mathrm{N}=1242)$

20) paid paternily leave

(contract lawyers)

women ( $N=307$ )

$\operatorname{men}(\mathrm{N}=970)$
YES

$2.7 \%$

$3.1 \%$

$4.0 \%$

$3.3 \%$

$2.0 \%$

$1.3 \%$
No

DON'T

KNOW

$57.3 \%$

$66.8 \%$

$40.0 \%$

$30.2 \%$

$100 \%$

$100 \%$
TOTAL

$36.4 \%$

$100 \%$

$29.8 \%$

$100 \%$

1 This Table excludes those who indicated the benefit was not applicable and those who did not respond to the questions. This Table might to some extent exaggerate the availability of benefits. 
TABLE 9

\section{Frequency With Which Respondents \\ Observed or Personally Experienced Sexual Harassment ${ }^{\prime}$}

\section{NUMBER OF TIMES OBSERVED OR EXPERIENCED}

$\begin{array}{llllll}0 & 1-2 & 3-5 & 6-10 & >10 & \text { No } \\ \text { Response }\end{array}$

1) Women lawyers subjected to unwanted

sexual advances by other lawyers

$\begin{array}{lrrrrrr}\text { women } & 63.7 \% & 16.5 \% & 9.2 \% & 3.0 \% & 2.8 \% & 4.8 \% \\ \text { men } & 90.0 \% & 4.6 \% & 1.6 \% & .3 \% & .4 \% & 3.2 \%\end{array}$

2) Women lawyers subjected to unwanted sexual advances by clients

$\begin{array}{lcccccc}\text { women } & 59.8 \% & 20.8 \% & 9.0 \% & 3.0 \% & 1.8 \% & 5.5 \% \\ \text { men } & 86.8 \% & 6.1 \% & 1.5 \% & .4 \% & .2 \% & 5.0 \%\end{array}$

3) Men lawyers subjected to unwanted sexual advances by other lawyers

$\begin{array}{lllllll}\text { women } & 92.2 \% & 1.8 \% & .8 \% & 0 \% & 0 \% & 5.2 \% \\ \text { men } & 93.4 \% & 2.7 \% & .4 \% & .1 \% & .3 \% & 3.0 \%\end{array}$

4) Men lawyers subjected to unwanted sexual advances by clients

$\begin{array}{lllllll}\text { women } & 86.5 \% & 6.3 \% & 1.2 \% & 0 \% & 0 \% & 6.0 \% \\ \text { men } & 87.8 \% & 5.2 \% & 1.4 \% & .3 \% & .4 \% & 4.8 \%\end{array}$

5) Women lawyers subjected to unwanted teasing. jokes, or comments of a sexual nature by other lawyers

$\begin{array}{lcccccc}\text { women } & 31.3 \% & 18.5 \% & 13.8 \% & 8.7 \% & 23.7 \% & 4.0 \% \\ \text { men } & 64.1 \% & 16.2 \% & 9.3 \% & 2.8 \% & 3.8 \% & 3.6 \%\end{array}$

6) Women lawyers subjected to unwanted teasing. jokes, or comments of a sexual nature by clients

$\begin{array}{lcccccc}\text { women } & 42.0 \% & 22.5 \% & 11.0 \% & 7.2 \% & 10.8 \% & 6.5 \% \\ \text { men } & 75.5 \% & 10.8 \% & 4.6 \% & 1.6 \% & 1.2 \% & 6.3 \%\end{array}$

7) Men lawyers subjected to unwanted teasing. jokes, or comments of a sexual nature by other lawyers

$\begin{array}{lllllll}\text { women } & 73.2 \% & 11.3 \% & 5.7 \% & 2.0 \% & 3.0 \% & 4.8 \% \\ \text { men } & 77.0 \% & 9.4 \% & 5.2 \% & 1.6 \% & 2.7 \% & 4.1 \%\end{array}$


Table 9 cont.

NUMBER OF TIMES OBSERVED OR EXPERIENCED

$\begin{array}{llllll}0 & 1-2 & 3-5 & 6-10 & >10 & \text { No } \\ \text { Response }\end{array}$

8) Men lawyers subjected to unwanted teasing, jokes, or comments of a sexual nature by clients

$\begin{array}{lrrrrrr}\text { women } & 82.5 \% & 7.3 \% & 2.7 \% & .2 \% & .7 \% & 6.7 \% \\ \text { men } & 82.9 \% & 5.8 \% & 2.6 \% & 1.1 \% & 1.3 \% & 6.3 \%\end{array}$

9) Support staff subjected to unwanted sexual advances by lawyers

$\begin{array}{lrrrrrr}\text { women } & 72.0 \% & 11.5 \% & 6.0 \% & 2.0 \% & 3.2 \% & 5.3 \% \\ \text { men } & 82.8 \% & 8.5 \% & 2.8 \% & 1.4 \% & .7 \% & 3.8 \%\end{array}$

10) Support staff subjected to unwanted sexual advances by clients

$\begin{array}{lrrrrrr}\text { women } & 72.7 \% & 11.8 \% & 5.7 \% & 1.5 \% & 1.8 \% & 6.5 \% \\ \text { men } & 79.8 \% & 9.6 \% & 3.7 \% & .8 \% & .4 \% & 5.6 \%\end{array}$

II) Support staff subjected to unwanted teasing, jokes, or comments of a sexual nature by lawyers

$\begin{array}{lcccccc}\text { women } & 51.2 \% & 16.0 \% & 10.2 \% & 4.3 \% & 12.5 \% & 5.8 \% \\ \text { men } & 70.4 \% & 12.6 \% & 7.0 \% & 2.4 \% & 3.6 \% & 4.0 \%\end{array}$

12) Support staff subjected to unwanted teasing. jokes, or comments of a sexual nature clients

$\begin{array}{lllllll}\text { women } & 61.7 \% & 14.5 \% & 8.7 \% & 2.2 \% & 5.5 \% & 7.5 \% \\ \text { men } & 73.5 \% & 12.5 \% & 5.1 \% & 1.5 \% & 1.7 \% & 5.7 \%\end{array}$

I Percentages are out of the 600 women and 1798 men who responded to the questionnaire. 
TABLE 10

Frequency With Which Respondents Were Denied Opportunity To Work On a File Because a Client Preferred a Lawyer of the Opposite Gender

FREQUENCY

often

sometimes

rarely

never

don't know

no response

TOTAL
WOMEN

$18(3.0 \%)$

$160(26.7 \%)$

$120(20.0 \%)$

$140(23.3 \%)$

$132(22.0 \%)$

$30(5.0 \%)$

$600(100 \%)$ 


\section{TABLE 11}

Frequency With Which Respondents Were Denied Opportunity To Work On a File Because a Lawyer in Their Firm Preferred a Lawyer of the Opposite Gender

$\begin{array}{lcc}\begin{array}{l}\text { FREQUENCY } \\ \text { WOMEN }\end{array} & \text { MEN } \\ \text { often } & 42(7.0 \%) & 4(.2) \\ \text { sometimes } & 107(17.8 \%) & 25(1.4 \%) \\ \text { rarely } & 70(11.7 \%) & 63(3.5 \%) \\ \text { never } & 217(36.2 \%) & 1343(74.7 \%) \\ \text { don't know } & 124(20.7 \%) & 2.51(14.0 \%) \\ \text { no response } & 40(6.7 \%) & 112(6.2 \%) \\ \text { TOTAL } & 600(100 \%) & 1798(100 \%)\end{array}$




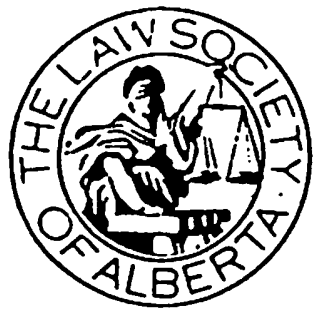

\section{Survey of Active Members of The Law Society of Alberta}

1. How are you primarily employed? How would you prefer to be employed?

(Check one each)

$\begin{array}{ccl}\text { Present } & \text { Preferred } \\ \square & \square & \text { sole practitioner on own } \\ \square & \square & \text { office sharing with other practitioner(s) } \\ \square & \square & \text { associate in or employee of a law firm } \\ \square & \square & \text { partner in a law firm } \\ \square & \square & \text { government lawyer (employec) } \\ \square & \square & \text { government lawyer (contract) } \\ \square & \square & \text { other government position } \\ \square & \square & \text { industry or corporate counsel } \\ \square & \square & \text { legal education } \\ \square & \square & \text { society or union } \\ \square & \square & \text { contract research } \\ \square & \square & \text { community law office/public interest } \\ \square & & \text { advocate } \\ \square & \square & \text { judge } \\ \square & \square & \text { unemployed } \\ \square & \square & \text { other (please specify) }\end{array}$

2. If you are working, are you working

$\begin{array}{ll}\square & \text { full time } \\ \square & \text { full time, but seeking part time or job sharing } \\ \square & \text { part time or job sharing } \\ \square & \text { part time or job sharing, but seeking full time }\end{array}$

3. What is the size of the community within which you work?
口 100,000 or more
口 $\quad 50,000-99,999$
口 $\quad 10,000-49.999$
口 Under 10,000

4. How long have you practised law in all jurisdictions (do not include articles)?

years

5. When were you called to the Bar in Alberta? 19

6. Since your call in Alberta, how long in total have you spent not practising law and at the same time looking for a position in practice?

— years

7. Since your call in Alberta, how many different jobs have you had in each of the following categories, excluding moves within the same firm or organization:

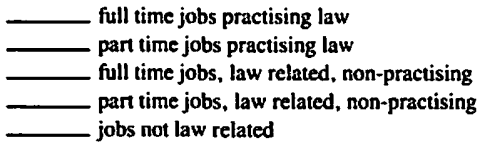

8. How many of the "practising law" jobs in Question 7 ended for reasons other than your choice? jobs

If any of your "practising law" jobs ended for reasons other than your choice and you wish to elaborate on the circumstances, please use a separate page and identify your response as relating to question 8 .

9. How likely is it (0-100\%) that you will look for a new job within the next year? 
10. How satisfied are you with the following aspects of your work?

\begin{tabular}{|c|c|c|c|c|c|c|c|}
\hline & \multicolumn{3}{|c|}{$\begin{array}{l}\text { very } \\
\text { satisfied }\end{array}$} & \multicolumn{4}{|c|}{$\begin{array}{r}\text { very } \\
\text { dissatisfied }\end{array}$} \\
\hline & 1 & 2 & 3 & 4 & 5 & 6 & 7 \\
\hline nature of work & $\square$ & $\square$ & 口 & $\square$ & $\square$ & $\square$ & D \\
\hline hours of work & 口 & $\square$ & $\square$ & $\square$ & $\square$ & 口 & $\square$ \\
\hline job security & $\square$ & $\square$ & $\square$ & 口 & $\square$ & $\square$ & $\square$ \\
\hline money & $\square$ & $\square$ & $\square$ & $\square$ & 口 & $\square$ & 口 \\
\hline prestige of work & 口 & $\square$ & 口 & 口 & $\square$ & $\square$ & $\square$ \\
\hline control over work & $\square$ & $\square$ & $\square$ & 口 & 口 & प & \\
\hline opportunity for advancement & 口 & $\square$ & $\square$ & $\square$ & 口 & 口 & 口 \\
\hline employment benefits & 0 & D & $\square$ & 口 & $\square$ & 口 & \\
\hline $\begin{array}{l}\text { working relationship wi } \\
\text { female colleagues }\end{array}$ & 口 & $\square$ & $\square$ & 口 & $\square$ & 口 & U \\
\hline male colleagues & 口 & $\square$ & 口 & $\mathbf{\square}$ & $\square$ & 口 & \\
\hline administration & 口 & $\square$ & $\square$ & $\square$ & $\square$ & $\square$ & \\
\hline support staff & $\square$ & $\square$ & $\square$ & 口 & $\square$ & 口 & प \\
\hline balance with person & U & $\square$ & D & J & 口 & 口 & \\
\hline
\end{tabular}

11. What degree of control do you have over your work?

$\begin{array}{ll}\square & \text { minimal } \\ \square & \text { some } \\ \square & \text { primary, except for major decisions } \\ \square & \text { complete }\end{array}$

12. How many weeks of vacation did you take in the last year? weeks

13. In the last 5 years, how often have you been involved in: often sometimes rarcly never N/A

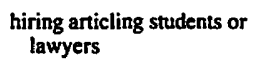

14. a) In the last year, approximately what percentage of your working time was spent on the following:

\begin{tabular}{l} 
\% administrative work \\
\% promotion and client development \\
\% practising law \\
\% uncompensated law related work (e.g., \\
Continuing Legal Education, legal aid and Law \\
Society committees, CBA) \\
\% teaching \\
\% free legal advice \\
\% keeping up-to-date \\
\% other (please specify) \\
\hline 100\% TOTAL
\end{tabular}

14. b) How satisfied are you with the division of your work as set out in question 14(a)?

\begin{tabular}{lcccccc} 
very satisfied & & & \multicolumn{2}{r}{ very dissatisfied } \\
1 & 2 & 3 & 4 & 5 & 6 & 7 \\
$\square$ & $\square$ & $\square$ & $\square$ & $\square$ & $\square$ & $\square$
\end{tabular}

If you are dissatisfied with this division of your work and wish to elaborate on your dissatisfaction, please use a separate page and identify your response as relating to question 14 .

15. How many hours do you generally work per week? (Include all of the categories in question 14(a).) hours per week

16. Rank the three areas in which you spent the most time practising law during the last year, with " 1 " indicating the most time. Would you prefer to spend more time or less time in each of these three areas?

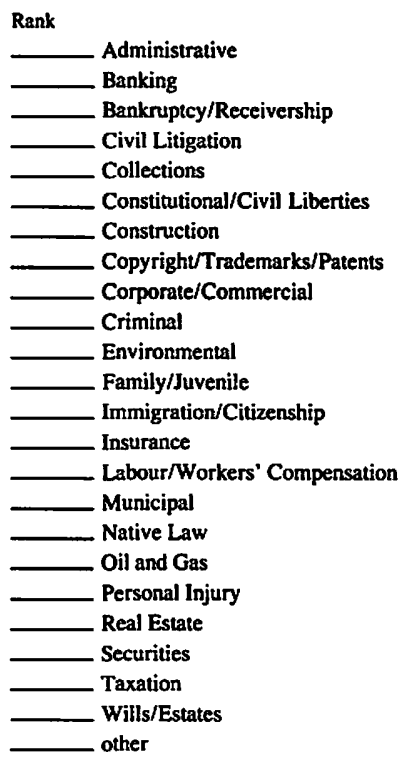

$\begin{array}{cc}\text { Prefer } & \text { Prefer } \\ \text { more } & \text { Less } \\ \square & \square \\ \square & \square \\ \square & \square \\ \square & \square \\ \square & \square \\ \square & \square \\ \square & \square \\ \square & \square \\ \square & \square \\ \square & \square \\ \square & \square \\ \square & \square \\ \square & \square \\ \square & \square \\ \square & \square \\ \square & \square \\ \square & \square \\ \square & \square \\ \square & \square \\ \square & \square \\ \square & \square \\ \square & \square \\ \square & \square \\ \square & \square\end{array}$

17. To what extent did the following factors influence your decision to work in the above areas?

personal interest great deal not at all availability of job employer assignments availability of clients your gender other (please specify)

$\begin{array}{lllllll}1 & 2 & 3 & 4 & 5 & 6 & 7\end{array}$

$\begin{array}{lllllll}\square & \square & \square & \square & \square & \square & \square\end{array}$

뭄ㅁㅁ

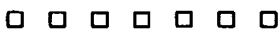
ㅁㅁㅁㅁㅁ

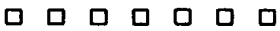

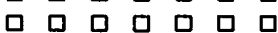


18. How many lawyers are there in your firm or organization who practise law in Alberta?
$\square$ one
ㅁ 20-35
ㅁ $2-4$
ㅁ 36-49
口 5.9
ㅁ $50-74$
ㅁ 10-19
ㅁ $75+$

19. What percentage of the lawyers in your firm or organization are women? - \%

20. In the last 5 years, do you feel you have been denied an opportunity to work on a file:

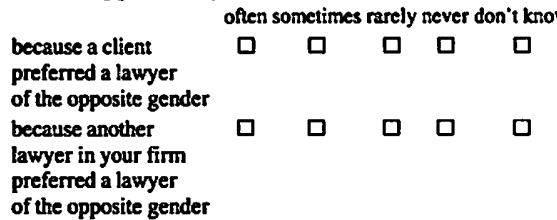

If you have been denied such an opportunity and wish to elaborate on the circumstances, please use a separate page and identify your response as relating to question 20 .

21. Are the following benefits offered to lawyers by your firm or employer?

\begin{tabular}{|c|c|c|c|}
\hline & & & \\
\hline disability insurance & 口 & 口 & c \\
\hline part time work & 口 & 口 & c \\
\hline $\begin{array}{l}\text { flexible work hours } \\
\text { (full time work) }\end{array}$ & ם & 口 & \\
\hline job sharing & 口 & $\square$ & గ \\
\hline $\begin{array}{l}\text { unpaid maternity leave for: } \\
\text { partners }\end{array}$ & व & $\square$ & [ \\
\hline associates/employees & 口 & $\square$ & \\
\hline contract lawyers & $\square \square$ & $\square$ & \\
\hline $\begin{array}{l}\text { unpaid paternity leave for: } \\
\text { partners }\end{array}$ & 口 & 口 & c \\
\hline associates/employees & 口 & 口 & c \\
\hline contract lawyers & व & 口 & \\
\hline $\begin{array}{l}\text { paid maternity leave for: } \\
\text { partners }\end{array}$ & ㅁ & $\square$ & \\
\hline associates/employees & 口ם & Q & \\
\hline contract lawyers & $\square \square$ & $\square$ & \\
\hline $\begin{array}{l}\text { paid paternity leave for: } \\
\text { partners }\end{array}$ & 口 & 口 & \\
\hline associates/employees & व & $\square$ & 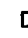 \\
\hline contract lawyers & 口ם & $\square$ & [ \\
\hline part time partnerships & 口 & $\square$ & c \\
\hline child care & 口 & 口 & 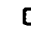 \\
\hline leave of absence/sabbatical & ם & $\square$ & L \\
\hline
\end{tabular}

22. a) If there is unpaid maternity leave for lawyers at your place of work, how much leave time is provided?

for partners
for associates/employees
for contract lawyers

22. b) If there is unpaid paternity leave for lawyers at your place of work, how much leave time is provided?

for partners
for associates/employees
for contract lawyers

23. a) If there is paid maternity leave for lawyers at your place of work (other than Unemployment Insurance benefits), how much leave time is provided?

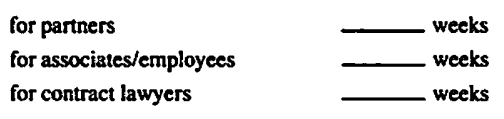

23. b) If there is paid paternity leave for lawyers at your place of work (other than Unemployment Insurance benefits), how much leave time is provided?

$\begin{array}{ll}\text { for partners } & \text { weeks } \\ \text { for associates/employees } & \text { weeks } \\ \text { for contract lawyers } & \text { weeks }\end{array}$

24. In the last 2 years, how many times have you personally observed or experienced the following types of behaviour in professional settings?

0 1-2 3-5 6-10 >10

women lawyers subjected to

unwanted sexual advances by:

other lawyers

clients

men lawyers subjected to unwanted sexual advances by:

other lawyers

clients

women lawyers subjected to

unwanted teasing, jokes, or

comments of a sexual nature by: other lawyers

clients

men lawyers subjected to unwanted

teasing, jokes, or comments of a

sexual nature by: other lawyers

clients

support staff subjected to unwanted sexual advances by: other lawyers

clients

ㅁㅁㅁㅁ

口 व $\square$

口 $\square$ 口

$\square \square \square \square \square$

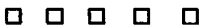

마 口

support staff subjected to unwanted teasing, jokes, or comments of a sexual nature by: other lawyers clients
ㅁㅁㅁ
ㅁㅁㅁ 
25. Which of the following best reflects the situation in your firm or organization today with regard to the hiring of articled students?
$\square$ men have a much better chance than women
$\square$ men have a slightly better chance than women
$\square$ men and women have an equal chance
$\square$ women have a slightly better chance than men
$\square$ women have a much better chance than men
$\square$ not applicable
$\square$ don't know

26. Which of the following best reflects the situation in your firm or organization today with regard to the hiring of lawyers?

$\square$ men have a much better chance than women

$\square$ men have a slightly better chance than women

$\square$ men and women have an equal chance

women have a slightly better chance than men

$\square$ women have a much better chance than men

$\square$ not applicable

don't know

27. Which of the following best reflects the situation in your firm or organization today with regard to the professional advancement of lawyers?
men have a much better chance than women
Den have a slightly better chance than women
$\square$ men and women have an equal chance
$\square$ women have a slightly better chance than men
$\square$ women have a much better chance than men
$\square$ not applicable
$\square$ don't know

\section{QUESTIONS 28-33 ARE FOR THOSE WHO} ARE IN PRIVATE PRACTICE. If you are not in private practice, please go to Quesiton 34.

28. If you bill by the hour, what is your usual hourly rate?

$\$$

29. Approximately how many billable hours did you record in the last year?

$$
\text { hours }
$$

30. If you are a partner, how many years did you practice law before you became a partner?

$$
\text { years } \square \text { not a partner }
$$

31. If there are partners in your firm, what percentage of the lawyers in your firm are partners?
32. If there are partners in your firm, what percentage of the partners in your firm are women?

—

33. Which of the following best reflects the situation in your firm today with regard to opportunities for partnership?

$\square$ men have a much better chance than women

$\square$ men have a slightly better chance than women

men and women have an equal chance

$\square$ women have a slightly better chance than men

$\square$ women have a much better chance than men

$\square$ not applicable

don't know

If men and women do not have an equal opportunity to become partners and you wish to elaborate on the circumstances, please use a separate page and identify your response as relating to question 33 .

\section{THE FOLLOWING QUESTIONS ARE FOR ALL RESPONDENTS.}

34. What is your perception of gender bias or discrimination against women in the legal profession in Alberta?
$\square$ there is none
$\square$ it exists, but is not widespread
$\square$ it is widespread, but subtle and difficult to detect
$\square$ it is widespread and readily apparent

35. What is your perception of gender bias or discrimination against men in the legal profession in Alberta?
$\square$ there is none
$\square$ it exists, but is not widespread
$\square$ it is widespread, but subtle and difficult to detect
$\square$ it is widespread and readily apparent

36. If you think there is gender bias or discrimination against women or men in the legal profession, how would you categorize it? (Check as many as appropriate.)
bias against:
women men

\begin{tabular}{lll}
\hline & $\square$ & $\begin{array}{c}\text { other lawyers not giving appropriate weight to } \\
\text { opinions }\end{array}$ \\
$\square$ & $\square$ & career advancement \\
$\square$ & $\square$ & access to clients \\
$\square$ & $\square$ & assignment of files/work \\
$\square$ & $\square$ & setting hourly rates \\
$\square$ & $\square$ & remuneration \\
$\square$ & $\square$ & hiring \\
$\square$ & $\square$ & attaining partnership \\
$\square$ & $\square$ & access to managerial positions \\
$\square$ & $\square$ & opportunity to appear in court \\
$\square$ & $\square$ & judicial attitudes
\end{tabular}




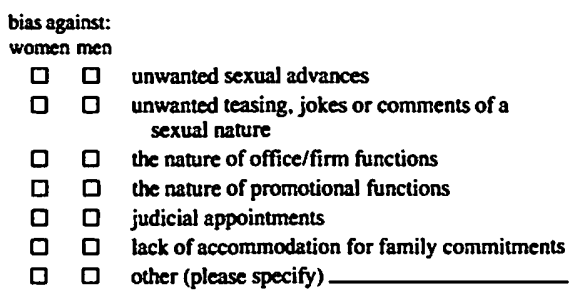

If you wish to explain or elaborate on any of the above forms of bias, please use a separate page and identify your response as relating to question 36 .

37. What was your pre-tax income from employment or self-employment in 1990 ?

s. .000
38. Are you
$\square$ male
口 female

39. In what year were you born?

19

40. Have you personally experienced discrimination while seeking employment as, or during the course of your employment as a lawyer, on the basis of any of the following (check as many as applicable):

$\begin{array}{ll}\text { sex } & \\ \text { colour or race } & \square \\ \text { disability } & \square \\ \text { age } & \square \\ \text { marital status } & \square \\ \text { sexual orientation } & \square \\ \text { parental status } & \square \\ \text { other (please specify) } & \\ \text { you experienced any problems and wish to } \\ \text { aborate on the circumstances, please use a } \\ \text { parate page and identify your response as } \\ \text { lating to question } 40 \text {. }\end{array}$

41. Are you, by virtue of your colour or race, in a visible minority?
$\square$ yes
no

42. For the purpose of employment, do you consider yourself disadvantaged by reason of a persistent disability?
$\square$ yes
口 no

43. Are you living in a married or equivalent relationship?
$\square$ yes
口 no

44. If you are living in a married or equivalent relationship, is your spouse:
a employed full time
口 employed part time
not employed

45. How many hours per week do you usually spend on household chores other than child care? hours per week

46. Which one of the following best describes the kind of work your parents usually did while you were growing up? (If you lived with a guardian for most of these years, please describe their kind of work instead.)

$\begin{array}{lcc}\text { owner of a business with }>10 \text { employees } & \square & \square \\ \text { owner of a business with } 1-10 \text { employees } & \square & \square \\ \text { self-employed, no employees } & \square & \square \\ \text { manager } & \square & \square \\ \text { employee } & \square & \square \\ \text { retired } & \square & \square \\ \text { homemaker } & \square & \square \\ \text { student } & \square & \square \\ \text { unemployed } & \square & \square \\ \text { other (please specify) } & \square & \square\end{array}$

47. Are or were any of the following of your relatives lawyers:
$\square$ grandmother
grandfather
$\square$ brother
$\square$ mother
sister
$\square$ father
spouse

\section{QUESTIONS 48-55 ARE FOR THOSE WHO ARTICLED IN ALBERTA DURING THE PERIOD 1980-1991 INCLUSIVE. If you are not in this category, please go to question 56.}

48. How many firms did you apply to for articles? firms

49. How many firms were prepared to interview you for articles?

_ firms

50. Did you experience any problems finding articles on the basis of:
ㅁ sex
$\square$ colour or race
disability
ㅁ marital status
口 age
$\square$ sexual orientation
$\square$ parental status
$\square$ other (please specify)

If you experienced any problems and wish to elaborate on the circumstances, please use a separate page and identify your response as relating to question 50 .

51. Did you get your first or second choice in articling positions?
$\square$ first choice
neither first nor second
$\square$ second choice

52. Did you stay with the firm you articled with for more than one year after articles?
$\square$ yes
n no 
53. a) If you left your firm within one year of articles, was it by choice?

$\square$ yes

no

53. b) If you left within a year, did you find another law-related position?

$\square$ yes $\square$ no

54. If you left your firm within one year of articles and found another law-related position:

a) how long did it take you to find your new position?

\section{months}

b) how satisfied were you with your new position? very satisfied

12

口

2

3

3

55. Approximately, where did you rank in your graduating class?
$\square \operatorname{top} 1 / 4$
a fourth $1 / 4$
$\square$ second $1 / 4$
$\square$ don't know
$\square$ third $1 / 4$

\section{THE REMAINING QUESTIONS ARE FOR THOSE WITH CHILDREN.}

56. How many children do you have? children

57. If you have children who require care (including feeding, supervision, attendance at sporting and school events, etc.):

a) what proportion of responsibility for that care is borne by each of the following:

\begin{tabular}{l} 
\% you \\
\% the person you live with \\
\% child's other parent (not living with you) \\
\% paid child care worker \\
\hline \% other \\
\hline $100 \%$ TOTAL
\end{tabular}

b) how many hours per week do you spend on this care? hours per week

58. If you have been involved in making child care arrangements, how much difficulty have you experienced?

\begin{tabular}{lllllll} 
none & & & & & \multicolumn{2}{c}{ a great deal } \\
1 & 2 & 3 & 4 & 5 & 6 & 7 \\
$\square$ & $\square$ & 0 & $\square$ & $\square$ & $\square$ & $\square$
\end{tabular}

59. To what extent have child care responsibilities affected your decisions in the following areas:

\begin{tabular}{llllllll} 
& none & \multicolumn{4}{c}{ a great deal } \\
choice of job & 1 & 2 & 3 & 4 & 5 & 6 & 7 \\
choice of specialty & $\square$ & $\square$ & $\square$ & $\square$ & $\square$ & $\square$ & $\square$ \\
choice of cases & $\square$ & $\square$ & $\square$ & $\square$ & $\square$ & $\square$ & $\square$ \\
hours of work & $\square$ & $\square$ & $\square$ & $\square$ & $\square$ & $\square$ & $\square$ \\
$\square$ & $\square$ & $\square$ & $\square$ & $\square$ & $\square$ & $\square$
\end{tabular}

THE REMAINING QUESTIONS ARE FOR THOSE WHO HAVE BECOME PARENTS SINCE 1985, AND WERE AT THE TIME ARTICLING OR CALLED TO THE ALBERTA BAR.

60. How many children have you had since 1985 ? children

61. Did you experience any of the following as a result of having children?
口 loss of seniority
口 delay in promotion
口 loss of office space
D pressure to return to work during parental leave
D pressure to work while on parental leave
u unreasonable work load following parental leave
- testing of commitment to work
$\square$ loss of clients
$\square$ loss of job
- difficulty in obtaining leave
- difficulty in obtaining flexible hours or part time work
口 loss of income
ㄴ. stress from competing demands
口 other (please specify)

62. When was your last child born?

19

63. a) How much maternity or paternity leave did you take when your last child was born? weeks

63. b) If you took leave, how sufficient was it?

\begin{tabular}{lcccccc} 
very sufficient & & \multicolumn{3}{r}{ very insufficient } \\
1 & 2 & 3 & 4 & 5 & 6 & 7 \\
$\square$ & $\square$ & $\square$ & $\square$ & $\square$ & $\square$ & $\square$
\end{tabular}

If your leave was insufficient and you wish to elaborate on the circumstances, please use a separate page and identify your response as relating to question 63 .

64. If you took parental leave when your last child was born, what percentage of your regular preleave income did payments from each of the following sources represent?

- \% Unemployment Insurance
\% disability insurance
\% payment from firm
\% other (please specify)
(Figures will add up to $100 \%$ ONLY if you received $100 \%$ of
your pre-leave income.)

Thank you for completing this survey. Please return it in the envelope provided. If you wish to elaborate on any aspect of this survey, please do so on a separate page. 